\title{
Green Rust: The Simple Organizing 'Seed' of all Life?
}

Michael J Russell

Planetary Chemistry and Astrobiology; Jet Propulsion Laboratory; California Institute of Technology, Pasadena, CA 91109-8099, USA;

E-Mail: michael.j.russell@jpl.nasa.gov

The most important problem of synthetic biology is...the reduction of carbonic acid.

and

Without the idea of spontaneous generation and a physical theory of life, the doctrine of evolution is a mutilated hypothesis without unity or cohesion.[1]

Leduc, [1]

\begin{abstract}
Korenaga and coworkers present evidence to suggest that 4.3 billion years ago the Earth's mantle was dry and water filled the ocean to twice its present volume.[2] $\mathrm{CO}_{2}$ was constantly exhaled during the mafic to ultramafic volcanic activity associated with magmatic plumes that produced the thick, dense and relatively stable oceanic crust. In that setting two distinct major types of sub-marine hydrothermal vents were active: $\sim 400^{\circ} \mathrm{C}$ acidic springs whose effluents bore vast quantities of iron into the ocean, and $\sim 120^{\circ} \mathrm{C}$, highly alkaline and reduced vents exhaling from the cooler, serpentinizing crust at some distance from the heads of the plumes. When encountering the alkaline effluents, the iron from the plume head vents precipitated out forming mounds likely surrounded by voluminous exhalative deposits similar to the banded iron formations known from the Archean. These mounds and the surrounding sediments likely comprising nanocrysts of the variable valence FeII/FeIII oxyhydroxide, green rust. The precipitation of green rust, along with subsidiary iron sulfides and minor concentrations of $\mathrm{Ni}, \mathrm{Co}$ and $\mathrm{Mo}$ in the environment at the alkaline springs may have established both the key bio-syntonic disequilibria, and the means to properly make use of them - those needed to drive the essential inanimate-to-animate transitions that launched life. In the submarine alkaline vent model for the emergence of life specifically it is first suggested that the redox-flexible green rust microcrysts spontaneously formed precipitated barriers to the complete mixing of carbonic ocean and alkaline hydrothermal fluids, barriers that created and maintained steep ionic disequilibria; and second, that the hydrous interlayers of green rust acted as 'engines' that were powered by those ionic disequilibria and drove essential endergonic reactions. There, aided by sulfides and trace elements acting as catalytic promoters and electron transfer agents, nitrate could be reduced to ammonia and carbon dioxide to formate, while methane may have been oxidized to methyl and formyl groups. Acetate and higher carboxylic acids could then have been produced from these $\mathrm{C} 1$ molecules and aminated to amino acids, and thence oligomerized to offer peptide nests to phosphate and iron sulfides and secreted to form primitive amyloid-bounded structures, leading conceivably to protocells.
\end{abstract}

Keywords: Hadean, carbonic ocean, mantle plumes, Banded Iron Formation, green rust, submarine alkaline vents, emergence of life 


\section{Introduction}

Chemistry unbridled, could not have led to life.[1,3,4]. Redox and $\mathrm{pH}$ gradients were required, together with 'engines of disequilibria conversion' to allow these gradients to do the work of surmounting the steep endergonic barriers encountered by $\mathrm{C} 1$ molecules that they might react and complexify along the pathways and, eventually, around the autocatalytic cycles of life, just as the autotrophs feeding the base of the food web do today. But what materials and what environments could have allowed these gradients to be used to drive the key endergonic processes needed to launch life? In our original alkaline hydrothermal vent (AHV) model we suggested that life emerged at an alkaline hydrothermal spring on meeting the carbonic Hadean Ocean.[5]). At the macro level the spontaneously precipitated sulfides and hydroxides could induce just the redox and $\mathrm{pH}$ gradients, and with the same polarities, as extant life. And the precipitate mounds could provide the conversion engines specific to the transformations that needed to be made in the ambient environment, sufficient to drive life's emergence.[3,4,6] But it became clear that mere porous cavities could not provide the low water activities and the pumps beyond the merely osmotic, to take on the requirements of an autotrophic metabolism, let alone its need for adaption, guidance and waste disposal. Moreover, a mineral seed has struck many as lacking the versatility of organic molecules whatever their provenance. So, when Arrhenius [7] also called upon a crystal as being a host mineral of biopoesis, it was not obvious then that a genuine epiphany had been realized.[7] Arrhenius' crystal group of choice were the Doppelschichtstrukturen mit brucitähnlichen first decribed by Allmann.[8,9] These double layer hydroxides (strictly the DLH though generally and mistakenly referred to as the layered double hydroxides $\mathrm{LDH})$ may be derived out of the brucite $\left(\mathrm{Mg}[\mathrm{OH}]_{2}\right)$ structure, especially significant in that brucite itself is often the first mineral to be precipitated at submarine alkaline hydrothermal vents today.[10,11,12] In the DLH proper, two thirds of the cations are divalent (e.g., $\mathrm{Mg}^{2+}, \mathrm{Fe}^{2+}, \mathrm{Ni}^{2+}, \mathrm{Zn}^{2+}, \mathrm{Ca}^{2+}, \mathrm{Co}^{2+}, \mathrm{Mn}^{2+}$ ) while every third cation carries a +3 charge (e.g., $\left.\mathrm{Al}^{3+}, \mathrm{Fe}^{3+}, \mathrm{Cr}^{3+}, \mathrm{Mn}^{3+}, \mathrm{Ni}^{3+}, \mathrm{Co}^{3+}\right)$. One such DLH, green rust $\left(\sim \mathrm{Fe}^{\mathrm{II}}{ }_{4} \mathrm{Fe}^{\mathrm{III}}{ }_{2}[\mathrm{OH}]_{12} \mathrm{CO}_{3} \cdot 3 \mathrm{H}_{2} \mathrm{O}\right)$, struck Arrhenius [7] as a particularly good candidate to consider in terms of life's emergence. It is pliant, contains hydrous interlayers that readily persorb anions and is both responsive and resilient to strong variations in $\mathrm{pH}$ and redox. We might think of these interlayers as the viscous 'innards', or even as proto-cytoplasm within the spontaneously precipitated and rechargeable green rust. Green rust, along with the subordinate iron sulfide mackinawite $([\mathrm{Fe}>\mathrm{Ni}] \mathrm{S})$, functioned, it is proposed, as electrochemical nano-engines acting to convert the imposed external proton and redox disequilibria into the internal disequilibria necessary to bring life into being.[6] These engines might effect 'free energy' conversions of various types driven by Brownian motion with built-in escapement mechanisms that prevent back reactions.[3,4,13 ] It is in this light that it should be possible to discern such recognizable mineral precursors in the geologic record to explain the autogenic emergence of metabolic pathways and cycles supplied from the simplest of carbon substrates, carbon dioxide, formate and methane. [14] In the AHV model, the complex molecular engines mediating present-day electron transfer and conversions are a result of evolution from such abiotic mineral ancestors. $[3,4,13]$

Thus, the nub of this contribution is to suggest how green rust $\left(\sim\left[\mathrm{Fe}^{2+}{ }_{6 \mathrm{x}} \mathrm{Fe}^{3+}{ }_{6(1-x)} \mathrm{O}_{12} \mathrm{H}_{2(7-3 \mathrm{x})}\right]^{2+} \cdot\left[\mathrm{CO}^{2-}{ }_{3} \cdot 3 \mathrm{H}_{2} \mathrm{O}\right]^{2-}\right)$, nickel-rich mackinawite $([\mathrm{Fe}>\mathrm{Ni}] \mathrm{S})$, greigite $\left(\mathrm{Fe}_{5} \mathrm{NiS}_{8}\right)$, violarite $\left(\mathrm{Fe}_{2} \mathrm{Ni}_{4} \mathrm{~S}_{8}\right)$ and possibly tochilinite $\left(\mathrm{FeS}\left[\mathrm{Mg}, \mathrm{Fe}^{2+}\right][\mathrm{OH}]_{2}\right)$, precipitated as the first response to the alkaline vent-versus-ocean interfacing, may have been co-opted, adapted and systematized as nano-engines and catalysts at a Hadean submarine alkaline mound, so enabling 
the emergence of life. $[15,16]$ That green rust is capable of conformational changes during oxidative-reductive and protonation-deprotonation oscillations lends itself to such investigations.[7,17,18,19] We also speculate on the crucial steps taken toward what must have been the break-out metabolism and an organic takeover of the mineral precursor disequilibrium or 'free energy' converters, as they acquire organic frameworks in a process that we have called 'minerobiolization'. We then review the status of efforts to test these and related ideas bearing on the issue and conclude with a rather long list of falsifiable predictions of the submarine AHV as it now stands! The transition from inorganic- toward partly organic-enabled molecular mechanisms was, we believe, just the very first of many subsequent evolutionary steps made through the adaption of a chance function derived in one context for use in another. In the text, references to analogous modern mechanisms to those considered to have first begat life can be thought of as the direct legacies from, and as being broadly homologous with, their mineral progenitors. With these assumptions in mind we will suggest a testable model whereby the first and simplest pathways and enzymatic mechanisms are assumed to reflect on early beginnings and availabilities of disequilibria, mechanisms for their conversion, as well as on the trace metals and phosphate that contributed to these processes then and now.

\section{Model assumptions}

The submarine AHV model for life's emergence focusses on the interaction between $\mathrm{C} 1$ molecules, and proton and electron gradients, acting across membranes for autogenesis.[20,21] The iron oxyhydroxides and sulfides comprising the membranes act as disequilibrium converters.[13,16] However, these and several other key aspects of the AHV theory need experimental testing, particularly at pressures high enough $(\sim 10$ bars $)$ to keep hydrogen, methane and $\mathrm{CO}_{2}$ in sterile solution. Nick Lane's group have had some success testing this autotrophic (autogenic) hydrothermal model for the emergence of life by attempting to reproduce molecules of the reductive acetyl coenzyme-A pathway (rAcCoA).[22]. This group tested an abiotic $\mathrm{CO}_{2-}$ fixing pathway employing a rig that models the submarine alkaline vent whereby $\mathrm{CO}_{2}$ dissolved in an acidulous ocean analog on one side of an FeS-bearing membrane is juxtaposed to an alkaline hydrothermal solution on the other.[23,24,25,26,27,28] An endergonic reaction was expected to be driven by the protons pent up in the ocean (the original and natural proton motive force) as they permeated the iron sulfide chimney toward the alkaline interior along a single pathway.[22,29,30] Yields of $\mathrm{CO}_{2}$ reduction products in these experiments were $\sim 50 \mu \mathrm{M}$ formate along with a variable and inconsistent formaldehyde concentration of around $100 \mathrm{nM}$. These authors speculate that the formaldehyde product should be enough to initiate the formose reaction and produce thereby, various sugars. However, formaldehyde is a significant contaminant in buildings and laboratories, which might explain the non-reproducibility of their results and give pause for thought.[31,32]

Ryuhhei Nakamura and his group have also provided partial experimental support for the AHV theory.[33] Using iron-nickel sulfides they demonstrate the electro-catalytic reduction of $\mathrm{CO}_{2}$, whereby the 3-4 $\mathrm{pH}$ units operating as the putative proton motive force (PMF) is "converted" to the $\sim 200 \mathrm{mV}$ over-potential required in the natural reduction.[33] Yamaguchi and collaborators caution that the PMF is rapidly expended through reduction of $\mathrm{H}^{+}$unless amines are to hand to substantially improve the Faradaic efficiency for $\mathrm{CO}_{2}$ reduction.[33,41] Rapid aminations of pyruvate to alanine have been demonstrated, and this amino acid would, through its amino site, substantially improve electron transfer reactions and the yield of reduced carbon 
species, and at the same time increase the durability of the membrane.[20,34,35,36,37,38] Much of any $\mathrm{H}_{2}$ generated in these conditions would be absorbed in the sulfides which could act as $\mathrm{H}_{2}$ stores as well as - through the re-reduction of the greigite to mackinawite - induce a homeostatic $\mathrm{pH}$ regulating mechanism. $[33,39,40]$ The two products of these electrochemical reductions are $\mathrm{CO}$ and $\mathrm{CH}_{4}$. Beyond the carbon monoxide, no intermediates such as formaldehyde or a methyl group, from which a metabolic pathway might be fed, are recorded.

More in line with the AHVT, an early experiment by Huber and Wächtershäuser did demonstrate the production of thioacetate directly from carbon monoxide using iron and/or nickel as catalysts in neutral and alkaline conditions.[42] Their experiment called for the activated-methyl group, methane thiol, generated from $\mathrm{CO}_{2}$ and $\mathrm{H}_{2} \mathrm{~S}$ or $\mathrm{FeS} / \mathrm{HCl}$ and $\mathrm{H}_{2} \mathrm{~S}-$ an ostensibly autotrophic reaction.[44] However, yields of the methane thiol were limited to $0.1 \%$ of the $\mathrm{H}_{2} \mathrm{~S}$ feed, the initial concentration of which was $\sim 1 \mathrm{mM} / \mathrm{L}$ at most, suggestive of a $\leq 1$ $\mu \mathrm{M} / \mathrm{L}$ thiol concentration - less than one ten thousandth of the concentration of $\mathrm{CO}_{2}$ around the vent. $[43,45,46,47]$. That this experiment requires repeating is made the clearer by the fact that thiols are, against expectation, seemingly absent from submarine hot springs.[48] Nevertheless, these experiments do partially address Luduc's assertion that "The most important problem of synthetic biology is not so much the synthesis of the albuminoids as the reduction of carbonic acid" - an argument echoed by the mineralogist Goldschmidt, and given biochemical foundation by Fuchs. $[1,24,49,50]$

Thus, in the face of these results and speculations, it might seem perverse to suggest instead a two-route autogenic pathway to the metastable intermediates of life. However, as the submarine alkaline vent environment offers millimolar-levels of both the fully-reduced carbon end member $\mathrm{CH}_{4}$, as well as the stable fully-oxidized carbon end member $\mathrm{CO}_{2}$, we have formulated a hypothesis involving these feeds from either end of the full $\mathrm{C} 1$ redox span to produce activated acetate, the target molecule of the first step to metabolism.

$[23,24,51,52,53,54,55]$ This two-path model to activated acetate - an alternative possibility yet to be experimentally tested - has been termed 'denitrifying methanotrophic acetogenesis'. [54] In this model $\mathrm{CO}_{2}$ is reduced to formate or $\mathrm{CO}$ with electrons either initially provided by oxidation of FeII as in the experiments mentioned above, or by a reversal of the formate hydrogen lyase reaction.[15] At the same time the hydrothermal $\mathrm{CH}_{4}$ is converted to a methyl group in complex reactions involving molybdenum in a 2 -electron redox cluster that have its electrons drawn, one to the high electron acceptor nitrite generated in green rust, converting it to nitric oxide, while the other, now more strongly reducing electron, is accepted by a greigite $\left(\mathrm{Fe}_{5} \mathrm{NiS}_{8}\right)$ cluster (cf. CO-dehydrogenase).[54] The oxygen atom of the nitric oxide is activated by the high potential electron from the molybdenum center which now has the power to oxidize the methane to a methyl group.[54] The two lost electrons are replaced by those released on the oxidation of hydrothermal hydrogen at a NiFe (Ni-bearing greigite) center acting as a hydrogenase. The resulting methyl group is further oxidized to a formyl group and then sulfidized to methane thiol, the two uniting to form the activated acetate as in the Huber-Wächtershäuser experiment.[15,43,54] The electron acceptors in this modified AVT are nitrate and nitrite (the first 'breathing' entities of life) - derived from the nitrogen oxides produced mainly through cloud-to-cloud lightning and rained into the Hadean ocean.[54,56,57,58] Eventually reaching micromolar concentrations this oxidant, along with $\leq 350 \mathrm{mM}$ of carbon dioxide are carbureted to the mound's margins through secondary convection and entrainment (Figure 1, Table 1).

But how does such a scenario fit with what we now know of Hadean times? 


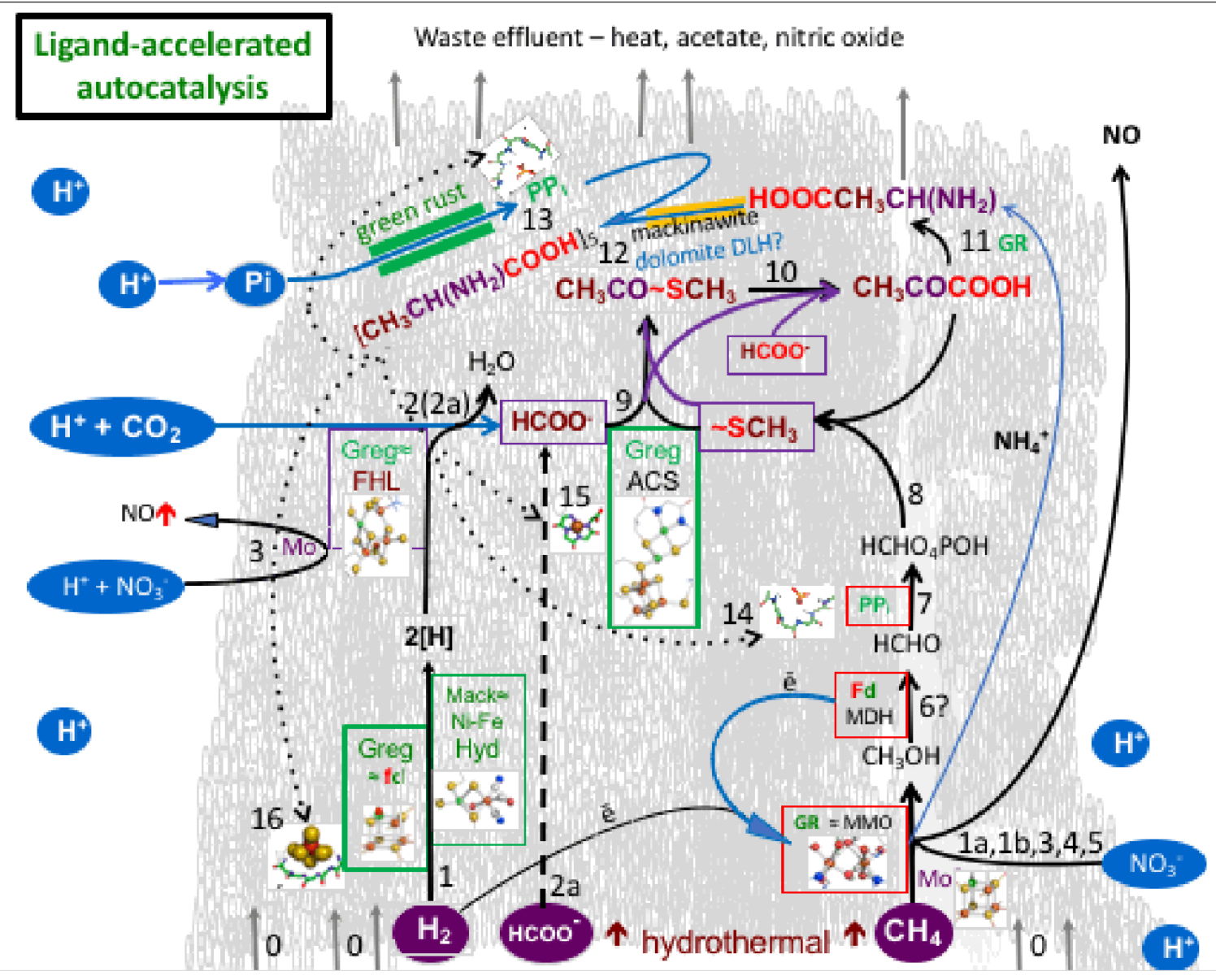

Figure 1. The proposed virtuous circle sketched here over a backdrop of a putative submarine green rust-mackinawite-greigite mound is intended to identify envisioned reactions demonstrated, or yet to be investigated in the lab - steps toward the first ligand-accelerated autocatalytic cycle (numbered reactions are specified in Table 1). It models denitrifying methanotrophic acetogenesis as the proposed pathway to the emergence of life in a submarine alkaline hydrothermal mound.[54,219] This model was conceived partly as a response to the generally trivial and intermittent yields of methane in our hydrothermal experiments.[285] Note, given the high kinetic barrier to the reduction of carbon dioxide, a short cut to formate may have been initially offered by the serpentinization reaction.[285] As the main drivers to the overall process are the $\mathrm{pH}$ and redox vectors (likely involving molybdenum as an electron bifurcator) operating across the inorganic membrane, we predict that green rust will prove to act as a general redox and $\mathrm{pH}$ disequilibria-converting engine in, and comprising, the membrane, supported by FeNi-sulfide catalysis. [15,16,28,54,150,286,290,293,294] The conditions responsible for these putative steps were probably localized somewhere on the very margins of the mound and are only separated on this sketch for ease of cognition. 
Table 1. Steps toward ligand-accelerated autocatalytic denitrifying methanotrophic acetogenesis: demonstrated, probable, possible and predicted, with comparisons to enzymes.

\begin{tabular}{|c|c|c|c|}
\hline $\begin{array}{l}\text { Biosyntonically 'engineered' steps } \\
\text { cf. prebiotic enzyme analogues }\end{array}$ & $\begin{array}{l}\text { Mineral barriers, } \\
\text { engines, catalysts }\end{array}$ & $\begin{array}{l}\text { Abiotic reaction } \\
\text { coupling and/or } \\
\text { gradient }\end{array}$ & References \\
\hline 0. $\begin{aligned}\left\{5 \mathrm{OH}^{-}+\mathrm{HS}^{-}\right\} & +2 \mathrm{Fe}^{2+}+\mathrm{Fe}^{3+}+\mathrm{Ni}^{2+} \\
& \rightarrow\left\{\mathrm{FeS}+\mathrm{Fe}_{2}(\mathrm{OH})_{5}\right\}+\overline{\mathrm{e}} \quad \text { membrane }\end{aligned}$ & $\begin{array}{l}\text { Green Rust \& [FeNi]S } \\
\text { set in } \mathrm{SiO}_{2} \text { ? }\end{array}$ & $\begin{array}{l}\text { spontaneous barrier } \\
\text { precipitation }\end{array}$ & $40,45,299$ \\
\hline 1. $\mathrm{H}_{2} \rightarrow 2 \mathrm{H} \bullet 2 \mathrm{H}^{+}+2 \mathrm{e}^{-}$ & $\begin{array}{l}\mathrm{GR}>\mathrm{FeS}>\mathrm{NiS}>\mathrm{MoS}_{2} / \\
\text { chimneys }\end{array}$ & redox gradient & 126,129 \\
\hline 1a. proton-coupled electron transfer processes fd & $\begin{array}{l}\text { GR, mackinawite, } \\
\text { greigite }\end{array}$ & proton gradient & 103 \\
\hline $\begin{array}{l}\text { 1b. electron bifurcation, conformation plasticity, } \\
\text { electron and proton transfer, gating MMO,Nir }\end{array}$ & $\begin{array}{l}\text { GR, mackinawite, } \\
\text { greigite, } \mathrm{MoS}_{x}\end{array}$ & redox gradient & $6,18,28,123$ \\
\hline 2. $\mathrm{H}^{+}+2 \overline{\mathrm{e}}+\mathrm{CO}_{2} \rightarrow \mathrm{HCOO}^{-}+\mathrm{H}_{2} \mathrm{O}$ & $\begin{array}{c}\mathrm{Ni}_{3} \mathrm{Fe}, \text { or }[\mathrm{FeNi}] \mathrm{S} \text { or } \\
\text { MoS }\end{array}$ & $\begin{array}{l}\text { serpentinization, or } \\
\text { redox, } \mathrm{pH} \text { gradient, }\end{array}$ & $\begin{array}{l}22,141,285 \\
300,301\end{array}$ \\
\hline 2a. $\mathrm{CO}_{2}+2 \overline{\mathrm{e}}+\mathrm{H}^{+} \rightarrow \mathrm{CO}+\mathrm{OH}-$ & violarite & electron conduction & 33,297 \\
\hline 3. $\mathrm{CH}_{4}+\mathrm{NO}_{3}^{-}+\mathrm{H}_{2}+\mathrm{H}^{+} \rightarrow \cdot \mathrm{CH}_{3}+2 \mathrm{H}_{2} \mathrm{O}+\underset{\text { MMO }}{\mathrm{NO}}$ & $\begin{array}{l}\text { GR \& Mo-dosed } \\
\text { greigite (redox/ } \\
\text { pH gradients) }\end{array}$ & $\begin{array}{l}\text { redox and } \mathrm{pH} \\
\text { gradient } \\
\text { undemonstrated }\end{array}$ & $\begin{array}{l}103,219,287 \\
293,294\end{array}$ \\
\hline 4. $\mathrm{NO}_{3}^{-}+4 \mathrm{H}_{2}+2 \mathrm{H}^{+} \rightarrow \mathrm{NH}_{4}^{+}+3 \mathrm{H}_{2} \mathrm{O}$ Nar/Nir/NOR & $\begin{array}{l}\mathrm{GR} \text { (redox/ pH } \\
\text { gradients) }\end{array}$ & redox ( 180 mins) & 161,168 \\
\hline $\begin{array}{r}\left.\text { 5. } \cdot \mathrm{CH}_{3}+\mathrm{OH}^{-} / \mathrm{SH}^{-} \text {?) } \rightarrow \mathrm{CH}_{3} \mathrm{OH} / \mathrm{CH}_{3} \mathrm{SH}\right)+\overline{\mathrm{e}} \\
\text { MMO? }\end{array}$ & GR? high T & undemonstrated & None \\
\hline 6. $\mathrm{CH}_{3} \mathrm{OH}+\left[2 \mathrm{Fe}^{\prime \prime \prime}\right] \rightarrow \mathrm{HCHO}+\left[2 \mathrm{Fe}^{\prime \prime}\right]+2 \mathrm{H}^{+}$ & $\begin{array}{l}\mathrm{GR}[\mathrm{FeNi}] \mathrm{S} ? \\
\mathrm{Fe}_{2}\left(\mathrm{MoO}_{4}\right)_{3}\end{array}$ & undemonstrated & 192 \\
\hline $\begin{array}{r}\text { 7. } \mathrm{HCHO}+\mathrm{HP}_{2} \mathrm{O}_{7}^{3-}+\left[\mathrm{OH}^{-}\right] \rightarrow\left[\mathrm{HCOPO}_{4}\right]^{2-}+\mathrm{HPO}_{4}^{2-} \\
\text { FK }\end{array}$ & $?$ & $\begin{array}{l}\text { exergonic but } \\
\text { undemonstrated }\end{array}$ & 133 \\
\hline 8. $\mathrm{HCOPO}_{4}^{2-}+\mathrm{HS}^{-}+2 \mathrm{H}^{+}+2 \overline{\mathrm{e}} \rightarrow \mathrm{CH}_{3} \mathrm{~S}^{-}+\mathrm{HPO}_{4}^{2-}$ & $?$ & $\begin{array}{l}\text { exergonic but } \\
\text { undemonstrated }\end{array}$ & 133,296 \\
\hline 9. $\mathrm{CH}_{3} \mathrm{~S}^{-}+\mathrm{HCOO}^{-}+\mathrm{H}^{+} \rightarrow \mathrm{CH}_{3} \mathrm{COOH}+\mathrm{HS}^{-}$ACS & $\mathrm{Fe}_{4} \mathrm{NiS}_{9}(\mathrm{HN})_{2}$ & cf. Reppe chemistry, & $29,43,288$ \\
\hline 9a. $\mathrm{CH}_{3} \mathrm{~S}^{-}+\mathrm{CO} \rightarrow \mathrm{CH}_{3} \mathrm{COS}^{-}$ & $\mathrm{Fe}_{4} \mathrm{NiS}_{9}(\mathrm{HN})_{2}$ & High yield (20 hours) & 42 \\
\hline 9b. $\left(\mathrm{CH}_{3} \mathrm{COS}^{-}+\mathrm{HPO}_{4}{ }^{2-} \rightarrow \mathrm{CH}_{3} \mathrm{COPO}_{4}{ }^{2-}+\mathrm{HS}^{-}\right)$ & $?$ & low yield & 302 \\
\hline 10. $\begin{aligned} & \mathrm{HCOO}^{-}+\mathrm{CH}_{3} \mathrm{CO} \sim \mathrm{SCH}_{3}+\overline{\mathrm{e}} \rightarrow \mathrm{HSCH}_{3}{ }^{-} \mathrm{CH}_{3} \mathrm{COCOO}^{-}+ \\
& \text {PFL }\end{aligned}$ & $\mathrm{Fe}_{2}(\mathrm{RS})_{2}(\mathrm{CO})_{6}$ & undemonstrated & 217,289 \\
\hline $\begin{array}{l}\text { 10a. } \mathrm{CH}_{3} \mathrm{COCOO}+\left(\left(\mathrm{HP}_{2} \mathrm{O}_{7}\right)^{3-}+\mathrm{CO}_{2} \rightarrow\right. \\
\mathrm{CH}_{2} \mathrm{C}=\mathrm{C}\left(\mathrm{OPO}_{3}\right)^{2-} \mathrm{COO}^{-}+\mathrm{HPO}_{4}{ }^{2-}+\mathrm{H}^{+}\end{array}$ & GR/mackinawite? & predicted & 16 \\
\hline
\end{tabular}




\begin{tabular}{|c|c|c|c|}
\hline $\begin{array}{l}\text { 10b. } \mathrm{CH}_{2}=\mathrm{C}\left(\mathrm{OPO}_{3}\right)^{2-} \mathrm{COO}^{-}+\mathrm{CO}_{2}+\mathrm{H}_{2} \mathrm{O} \rightarrow \\
\mathrm{O}^{-\mathrm{OCCH}_{2} \mathrm{COCOO}^{-}+\mathrm{HPO}_{4}^{2-}+\mathrm{H}^{+}} \quad \text { ACC }\end{array}$ & GR/mackinawite? & predicted & 16 \\
\hline $\begin{array}{l}\text { 11. } \mathrm{CH}_{3} \mathrm{COCOO}^{-}+\mathrm{NH}_{4}^{+}+2 \overline{\mathrm{e}}+2 \mathrm{H}^{+} \rightarrow \\
\mathrm{CH}_{3} \mathrm{CH}\left(\mathrm{NH}_{2}\right) \mathrm{COO}^{-}+\mathrm{H}_{2} \mathrm{O}\end{array}$ & GR/mackinawite? & 24 hours & 38 \\
\hline $\begin{array}{r}\text { 12. }\left(\mathrm{CH}_{3} \mathrm{CH}\left(\mathrm{NH}_{2}\right) \mathrm{COOH}\right)_{4}+\mathrm{CH}_{3} \mathrm{CH}\left(\mathrm{NH}_{2}\right) \mathrm{COOH} \rightarrow \\
\mathrm{CH}_{3} \mathrm{CH}\left(\mathrm{NH}_{2}\right) \mathrm{CO}-\mathrm{CH}_{3} \mathrm{CH}(\mathrm{NH}) \mathrm{CO}-\mathrm{CH}_{3} \mathrm{CH}(\mathrm{NH}) \mathrm{CO}- \\
\mathrm{CH}_{3} \mathrm{CH}(\mathrm{NH}) \mathrm{CO}-\mathrm{CH}_{3} \mathrm{CH}(\mathrm{NH}) \mathrm{COOH}+4 \mathrm{H}_{2} \mathrm{O} \\
\text { DLH [cf. "DNA pol"!] }\end{array}$ & $\begin{array}{c}\text { dolomite } \\
\text { (ab initio simulations } \\
\text { mackinawite and } \\
\text { double layer hydroxide) }\end{array}$ & $\begin{array}{l}\text { spontaneous } \\
\text { (dolomite) }\end{array}$ & $\begin{array}{l}199,290,291 \\
292,298\end{array}$ \\
\hline 13. $\mathrm{Pi}+\mathrm{Pi} \rightarrow \mathrm{PPi}$ by $\mathrm{GR}$ & FeS, GR & only at equilibrium & 16,181 \\
\hline \multicolumn{4}{|l|}{ ligand-assisted recapitulation? } \\
\hline $\begin{array}{r}\{13\} \text { poly-alanine peptide-strengthened } \\
\text { membrane? }\end{array}$ & $\begin{array}{l}\text { mineral-organic } \\
\text { framework }\end{array}$ & spontaneous & 45,125 \\
\hline$\{14\}$ SGAGKT peptide $+\mathrm{Pi} \quad \rightarrow \quad$ P-loop & 6 mer peptide & spontaneous & 239 \\
\hline $\begin{array}{r}\{15\} \mathrm{CH}_{3} \mathrm{CH}\left(\mathrm{NH}_{2}\right) \mathrm{CO}_{-} \mathrm{CH}_{3} \mathrm{CH}(\mathrm{NH}) \mathrm{CO}- \\
\mathrm{CH}_{3} \mathrm{CH}\left(\mathrm{NH}_{2}\right) \mathrm{CO}-\mathrm{CH}_{3} \mathrm{CH}\left(\mathrm{NH}^{2} \mathrm{COOH}+\mathrm{Ni}^{2+}\right. \\
\rightarrow \quad \mathrm{Ni}-\mathrm{CH}_{3} \mathrm{CH}\left(\mathrm{NH}_{2}\right) \mathrm{CO}-\mathrm{CH}_{3} \mathrm{CH}(\mathrm{NH}) \mathrm{CO}- \\
\quad \mathrm{CH}_{3} \mathrm{CH}(\mathrm{NH}) \mathrm{CO}-\mathrm{CH}_{3} \mathrm{CH}(\mathrm{NH}) \mathrm{COOH} \\
\\
\text { ATCUN motif }\end{array}$ & 4mer peptide & spontaneous & $\begin{array}{l}235,236,238 \\
295\end{array}$ \\
\hline $\begin{array}{l}\{16\}\left(\mathrm{Fe}_{4} \mathrm{NiS}\right)+\mathrm{CH}_{3} \mathrm{CH}\left(\mathrm{NH}_{2}\right) \mathrm{CO}-\mathrm{CH}_{3} \mathrm{CH}(\mathrm{NH}) \mathrm{CO}- \\
\mathrm{CH}_{3} \mathrm{CH}(\mathrm{NH}) \mathrm{CO}-\mathrm{CH}_{3} \mathrm{CH}(\mathrm{NH}) \mathrm{CO}- \\
\mathrm{CH}_{3} \mathrm{CH}(\mathrm{NH}) \mathrm{COOH} \\
\rightarrow\left[\mathrm{Fe}_{4} \mathrm{NiS}\right]-\mathrm{CH}_{3} \mathrm{CH}\left(\mathrm{NH}_{2}\right) \mathrm{CO}-\mathrm{CH}_{3} \mathrm{CH}(\mathrm{NH}) \mathrm{CO}- \\
\mathrm{CH}_{3} \mathrm{CH}(\mathrm{NH}) \mathrm{CO}-\mathrm{CH}_{3} \mathrm{CH}(\mathrm{NH}) \mathrm{CO}- \\
\mathrm{CH}_{3} \mathrm{CH}(\mathrm{NH}) \mathrm{COOH} \quad \text { Proto-fd, ACs, CODH }\end{array}$ & 6 mer peptide & partial demonstration & 189 \\
\hline $\begin{array}{l}\rightarrow\{16\}\{1\}\{2\}\{3\}\{4\}\{5\}\{6\}\{7\}\{8\}\{9\}\{10\}\{11\}\{12\}\{13\} \rightarrow \\
\text { repeat }\end{array}$ & $\begin{array}{l}\text { GR breakout } \\
\text { metabolism? }\end{array}$ & & Figure 1 \\
\hline
\end{tabular}

$\mathbf{A C C}=$ Acetyl-CoA carboxylase $; \mathbf{A C S}=$ Acetyl-CoA synthase $; \mathbf{A L T}=$ Alanine transaminase; ATCUN motif = Amino terminal $\mathrm{Cu}(\mathrm{II})$ and $\mathrm{Ni}(\mathrm{II})$ binding motif; $\mathbf{C O D H}=$ Carbon monoxide dehydrogenase; $($ DLH $=$ Double Layer Hydroxide; DNA pol = DNA polymerase); Fd = Ferredoxin; FHL = Formate hydrogen lyase; FK = Formate kinase; $\mathbf{H}^{+}$PPase $=$ proton pyrophosphatase $; \mathbf{M M O}=$ methane monooxygenase $; \mathbf{M D H}=$ methanol dehydrogenase; $\mathbf{N a r}=\underline{\text { nitrate }}$ reductase; $\mathbf{N i r}=$ nitrite reductase; $\mathbf{N O R}=$ nitric oxide reductase; NiFe[Mo]-H2ase $=\mathrm{NiFe}[\mathrm{Mo}]$-hydrogenase; $\mathbf{P F L}=$ Pyruvate formate lyase .

\section{The Hadean water world}

Prior to the advent of plate tectonics and following a rapid rain-out at $\sim 4.4 \mathrm{Ga}$, about two present-day ocean volumes likely enveloped an entirely submerged mafic Hadean crust comprising extensive igneous provinces fed by large mantle plumes. $[58,59,60,61,62,63,6465,66,67]$ Judging from a modern example, the Ontong Java Plateau (that portion distant from the collision zone with the Solomon Island Arc), Hadean crust would have lain several kilometers below sea level, well out of the way of the so-called Late Heavy Bombardment.[68,69,70,71] Moreover, early Hadean zircons also suggest derivation from a 
strictly chondritic (i.e., "primitive") magma reservoir through the 'heat-pipe' tectonics of mantle plumes.[72] And these zircons have none of the indicators for fractionation that might otherwise suggest the development of an emergent Hadean continental crust.[73,74] There really was no fresh water to be had.

Furthermore, conditions at the Hadean ocean surface were certainly less than clement! The length of the day was shorter, the UV flux destructive to molecules of any length or intricacy, the moon close, the tides twenty times stronger, and the weather an unchecked roiling maelstrom (Figure 1).[76,77] Thus, there were no candidate land-based 'birthing' pools to periodically dry out and 'drive' polymerization of 'in-falling organic compounds' to produce at best, a picomolar organic soup, which anyway would be of doubtful nutritious value. Such conditions lay nearly a billion years into the future, well after life's onset, and are in any case irrelevant to the emergence of life.[6,78,79]

Extrapolating backwards from early Archean exposures in Greenland, which may evidence the onset of plate tectonics, the Hadean ocean crust of this water-world was likely covered in green rust $\left(\sim\left[\mathrm{Fe}^{2+}{ }_{6 \mathrm{x}} \mathrm{Fe}^{3+}{ }_{6(1-\mathrm{x})} \mathrm{O}_{12} \mathrm{H}_{2(7-3 \mathrm{x})}\right]^{2+}\right.$. $\left.\left[\mathrm{CO}^{2-}{ }_{3} \cdot 3 \mathrm{H}_{2} \mathrm{O}\right]^{2-}\right)$ and silica gels derived from a myriad of sulfate-poor acidic $\sim 400^{\circ} \mathrm{C}$ hydrothermal springs. [80,81,82] These very hot springs were driven by heat from the mantle plumes and bore many tens of $\mathrm{mM}$ iron Fe into the Hadean carbonic ocean.[82] The $\mathrm{pH}$ of this ocean, as back-extrapolated and assuming equilibrium with $\mathrm{CO}_{2}$ and metal solubilities, has generally been over-estimated, a consequence of failing to factor in the 50-fold supersaturation of iron in carbonic fluid.[83] However, empirical evidence from iron-rich carbonic lakes in Cameroon suggest instead, a $\mathrm{pH}$ of 5 to 5.5, although such a low $\mathrm{pH}$ is not critical to the AHV theory.[83,84, 85] Green rust would only have precipitated from this acidulous ocean on meeting the alkaline hydrothermal fluids.[7,76,81,82,85,86,87,88,89,90] On burial, this green rust converted to the hematite and magnetite constituting the thinly laminated banded iron formations (BIFs) comparable to those we see today.[89,90] With a specific gravity of around 5 and interlayered with basalt/komatiite and chert with specific gravities of $\sim 2.9$ and 2.5 respectively, the Hadean crust was 'doomed' to founder back into the hot, dry mantle, so explaining its absence.[80]

\section{The precipitate mound at the submarine alkaline vent}

As noted, green rust would have been precipitated from iron derived ultimately from high temperature acidic springs. This iron had remained supersaturated until interfacing alkaline fluids.[83,89] A major source of such alkaline waters would have been "Lost City-type" moderate temperature alkaline springs. $(5,12,89,90,91,92,93]$ Subsidiary hydrothermal mackinawite $[\mathrm{Fe}>\mathrm{Ni}] \mathrm{S}$, greigite $\left.\sim \mathrm{Fe}_{5} \mathrm{NiS}_{8}\right)$, amorphous silica $\left(\mathrm{SiO}_{2}\right)$ and phosphates $\left(\sim \mathrm{Fe}^{\mathrm{II}}{ }_{3}\left[\mathrm{PO}_{4}\right]_{2} \cdot 8 \mathrm{H}_{2} \mathrm{O}\right)$ along with a few scattered grains of molybdenite, were likely to have been co-precipitates (Table 1, Figure 1). [20,28,34,45,85,93,94,95,96,97,98,99,100,101,102,103]

At alkaline hydrothermal vents in today's ocean, brucite $\left(\mathrm{Mg}[\mathrm{OH}]_{2}\right)$ - a single layer hydroxide - is an early precipitate.[12,92] Such a wet environment is seen by some as a fatal flaw in Submarine Alkaline Hydrothermal Vent (AHV) theory and they instead call upon wetdry cycling in surface pools and ponds. However, as Philip Ball reminds us, water is not only "life's solvent", but acts as a shell to, and interacts with, both proteins and their substrates.[104,105,106,107,108] Indeed, water composes $70-80 \%$ of the cell mass where it is deeply involved in the orchestration of cellular machinery.[109] Furthermore, all of the dehydration-driven polymerization reactions of life take place in water. That they all require the 
mediation of protein machines - both to control the water activity at the active site, but also to provide a means by which these inherently endergonic processes can be thermodynamically driven - merely brings forward what the 'mineral machines' of 'first life' must also be capable of doing (and must be shown to be capable of doing) (Figures 1 and 2).

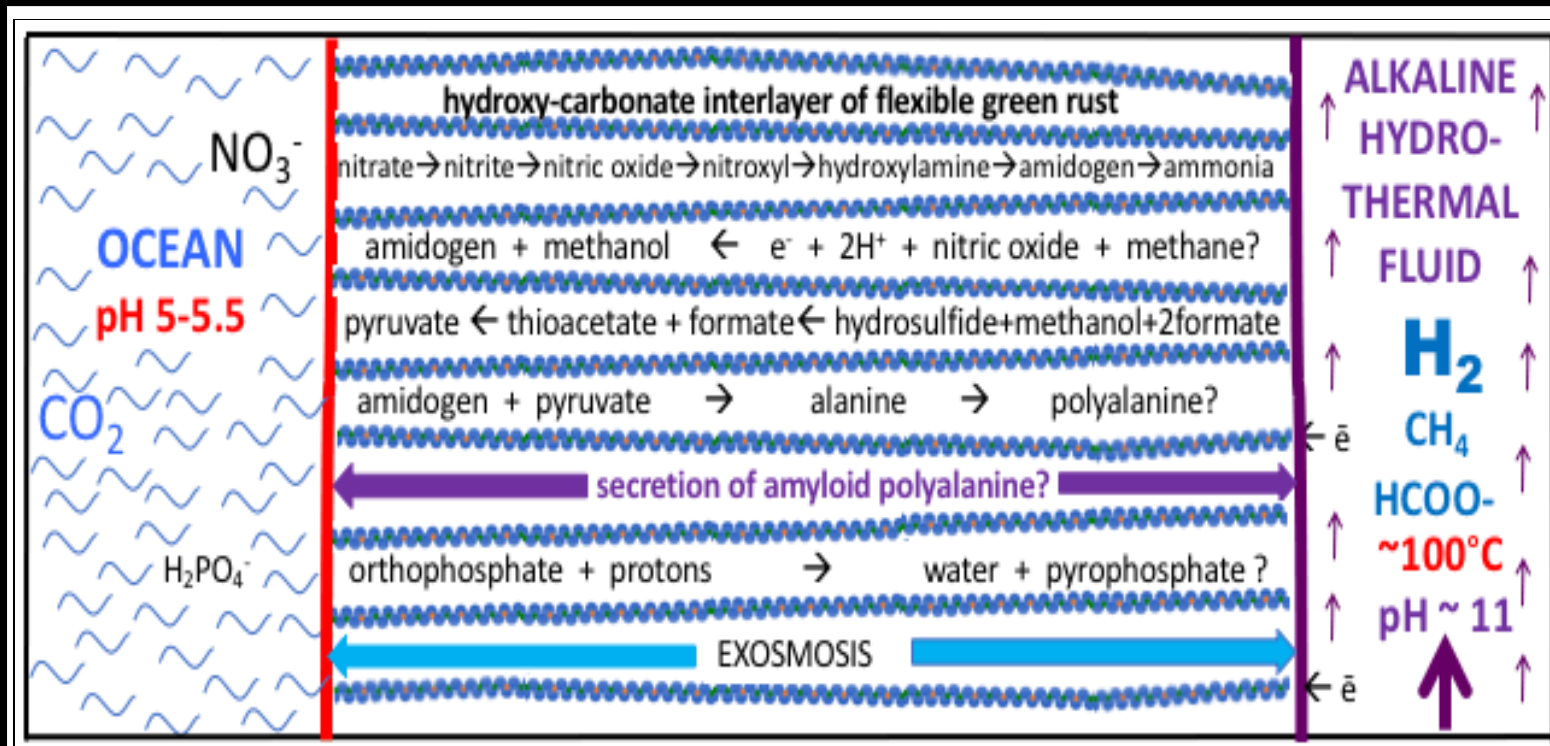

Figure 2. Cartoon of some of the feed molecules and expected products driven by redox and $\mathrm{pH}$ (electron and proton) gradients as mediated within the nano-galleries of green rusts situated in, and comprising, a barrier between alkaline hydrothermal solutions and the carbonic Hadean Ocean. See text, Figure 1 and Table 1. Not to scale. 
The rapidly precipitated nano-crystalline green rust and mackinawite comprising the alkaline mounds would also have included ambient water - confined and somewhat immobilized through hydrogen bonding in galleries $0.3 \mathrm{~nm}$ deep between the 'brucite' layers (e.g., in $\left.\left[\mathrm{Fe}_{4}{ }_{4} \mathrm{Fe}^{\mathrm{III}}{ }_{2}(\mathrm{OH})_{12}\right]\left[\mathrm{CO}_{3}\right] .3 \mathrm{H}_{2} \mathrm{O}\right)$. Thus, far from being a negative factor in the AHV theory for life's emergence, the intimate polar interfacing with constitutional water in green rust is just one of the many common features that could link such minerals to emergent

life. $[7,109,110,111,112,113]$ And the anions required for charge parity in green rust were engaged through ion-dipole interactions with FeIII/FeII cations.[114,115] In strong contrast, nano-confinement of water in mackinawite greatly enhances its self-dissociation, entailing no entropic cost and permits almost frictionless flow between the tetrahedral sheets.[116] Proton flow comparable to that in bulk water in these circumstances would have been via the Grotthuss mechanism at a rate of around $25 \mathrm{~nm} \mathrm{~ns}^{-1}$. [117] This is one of the reasons we are now persuaded that it was the green rust and mackinawite micro- and nano-crysts and their associated interlayer galleries filled with structured or 'bulk' water respectively that were life's cellular precursors, rather than the fluid-filled chambers or gels that we, and others, first imagined to have borne the first cytoplasm.[5,45]

In the living cell, for example, water molecules are hydrogen-bonding to iron in heme and iron hydroxylase, to magnesium in the ribosome, and, for a pertinent organic example, water molecules stabilize and activate C-methyltransferase.[118,119,120,121] So, although the founding submarine alkaline mound was completely immersed in water, bulk water was excluded at the site of some reactions in the interlayers of green rust and mackinawite, just as it is by proteins, or in lipid membranes. And these are the minerals that not only provided the spontaneously deposited barrier that kept the two contrasting fluids from immediate mixing, but also, dosed with trace elements $\mathrm{Ni}, \mathrm{Zn}$ and $\mathrm{Co}$, they constitute the inventory from the minéral trouvé that could have acted as nano-engines and electron transfer agents (i.e., disequilibrium converters and 'free energy' transformers) at life's emergence.[13,122,123] In the following we will examine the chief of these - the layered nanocrysts, green rust and mackinawite. Notably, these can be produced in the lab with $10 \mathrm{mmol}$ FeII iron concentrations, well below the many tens of mmol of iron in the $\sim 400^{\circ} \mathrm{C}$ spring sources mentioned above (Figures 1 and 2).[101,124,125] We will also touch on the likely, or possible, accompanying minor minerals, greigite, violarite and tochilinite. But we first consider the implication of a foundational presumption of the AHV theory: that life itself was driven into being by thermodynamic forces just as has also been, and by absolute necessity, every living thing since. What can we reasonably conjecture about what those original forces were that could have had that consequences?

\section{The disequilibria imposed across the mineral barrier}

Given that life, in its bid to hydrogenate carbon dioxide and, perhaps, oxidize methane to a methyl group, takes its power to do so from thermodynamically 'downhill' electron flow, it is reassuring to note demonstrations of electron generation sufficient to light LED bulbs at both actual and experimental hydrothermal vents.[105,126, 127,128,129] But whether electrons can also be harvested directly from hydrothermal $\mathrm{H}_{2}$ across an abiotic mineral membrane or more substantial barrier is still uncertain. Other possibilities considered below are that they are either delivered i) with formate, ii) through oxidation of methane by freshly precipitated Mo-dosed 
mackinawite or white rust, or iii) directly through the self-oxidation of nano-crysts of these metastable minerals (Table 1).[45,130]

It is well established that the tensions between volcanic carbon dioxide against the hydrogen exhaling into the acidulous ocean of young wet rocky planets, cannot be released through mere geochemical reactions beyond formate because of thermodynamic barriers.[29,58,131] Even electrochemical experiments involving steep over-potentials do not produce the chemical intermediates that populate autotrophic metabolic pathways such as methyl thioacetate $\left(\mathrm{CH}_{3} \mathrm{COSCH}_{3}\right)$ which requires assailing the thermodynamic barrier posed by formaldehyde.[131] However, the endergonic reduction of carbon dioxide through formate to a formyl group is achieved in biology by coupling it to any one of three types of exergonic driving reactions: 1) the relaxation of a proton gradient, 2) the hydrolysis of polyphosphates or 3) relaxing a redox gradient via electron bifurcation.[19,22,132,133,134,135] All of these disequilibria conversions must be, of course, carried out by macromolecular nano-engines (disequilibrium converters) and, as we have intimated, we have every reason to assume that nano-engines were coopted from the mineralized environment obtaining in the alkaline hydrothermal mound.[136,137,138] For reasons stated in section 2, we appeal to hydrothermal methane to provide reduced carbon from the other end of the redox scale to the system along with formate and now consider how this model corresponds to what is now known of the Hadean world.

The iron-rich mound generated at the alkaline vent offers an ambient trans-membrane proton motive disequilibrium or force ( $\Delta \mathrm{pH} 4$ to 5$)$ as emphasized by Herschy and his colleagues.[22] It also provides a redox gradient of $500 \mathrm{mV}$ or so comprising hydrogen plus methane versus nitrate and $\mathrm{Fe}^{\mathrm{III}}, \mathrm{Mn}^{\mathrm{IV}}$ plus carbon dioxide. At the same time hydrothermal hydrogen at $\sim 15 \mathrm{mmol} / \mathrm{kg}$ and formate at $\sim 150 \mu \mathrm{mol} / \mathrm{kg}$ are born towards, and focused at, the mound.[139,140,141,142] Hydrogen is the sine qua non electron donor used by all life still in the form of NADH.[143,144] Indeed, in this way billions upon billions of electrons are transported to the vent in hydrothermal solutions exhaling at $\sim 1000 \mathrm{~kg} / \mathrm{sec}$ in the present day.[145,146] Temperatures too were appropriate $\left(30^{\circ}\right.$ to $\left.100^{\circ} \mathrm{C}\right)$, as were pressures $(\geq 100$ bars), and longevity $\left(\sim 10^{20}\right.$ nanoseconds).[93] The trace metals required for catalysis would be precipitated with the sulfides and oxides on meeting the margins of the alkaline vent fluid.[125,147] However, as we have argued, endergonic reactions (a positive $\Delta \mathrm{G}$ ) can't be made to happen by mere catalysis, which can only reduce an activation energy, so mere catalysis cannot explain the emergence of life.[3,6] We need instead, nanoscale disequilibrium converters situated at the margins of the alkaline hydrothermal mound to take advantage of the various gradients imposed by the precipitation of relatively insoluble inorganic entities. This seems a tall order: that one or more of such mineral microcrystals might also act as the thermodynamic conversion engines driving emergent metabolism in the sense of Cottrell seems counter intuitive, viz., "The most promising path to solving this riddle appears at present to be through investigating whether" their local redox-state effects on gallery conformation, especially in green rust, could drive the needed proto-biosynthetic reactions while retaining their overall integrity.[148]

We hypothesize that the proton and electron gradients, as in life, have the theoretical potential to drive endergonic reactions toward a break-out metabolism.[16] For one thing, the disequilibrium between the redox couples $\mathrm{H}^{+} / \mathrm{H}_{2}$ and $\mathrm{NO}_{3}{ }^{-} / \mathrm{NO}_{2}{ }^{-}$of $\sim 800$ millivolts is also now well established.[58,150] $\mathrm{H}^{+} / \mathrm{H}_{2}$ and the $\mathrm{NO}_{3}{ }^{-} / \mathrm{NO}_{2}{ }^{-}$. Involved in electron bifurcation, the disequilibrium would have provided the over-potential required to have driven, for example, the reduction of carbon dioxide. And the proton gradient was steep, the $\mathrm{pH}$ of the Hadean ocean 
likely oscillated around $5 \mathrm{pH}$ units given the continual escape of $\mathrm{CO}_{2}$ from the so-called "popping rocks" comprising the ubiquitous mafic lava flows, and the empirical values reported from Lakes Nyos and Monoun in the Cameroon, as against the alkaline $(\mathrm{pH} \sim 11)$ hydrothermal solution, producing a gradient of 250 to 300 millivolts ( $1 \mathrm{pH}$ unit being equivalent to 59 $\mathrm{mV}) .[68,84,149]$ Thus the exact $\mathrm{pH}$ disequilibrium is not critical beyond offering a potential of $\sim 200 \mathrm{mV}$.

It should be noted here that ferrous carbonate remains super-saturated in these conditions. [83] The fact that both the oxyhydroxides and the sulfides can house substantial nickel concentrations in structures affine with active sites in the metalloproteins makes them promising promotors, disequilibrium converters ('free energy transducers') or nanomotors and electron transfer agents (protoenzymes) at life's emergence. However, the big question remains as to how these disequilibria were coupled to surmount those endergonic reactions along the pathways to metabolism.

Of course, a detailed research effort is required to reveal how protonic and electronic disequilibria could have been converted abiotically, presumably by the minerals discussed above, to do their work (Figure 2). One obstacle to understanding how exergonic processes are able to drive endergonic ones is quite counter intuitive.[13] For example, such driving does not involve the transfer of energy (even the 'free part' of a literal energy) from the driving process to the driven one. But rather. the engine managing the conversion makes individual fluctuation events dissipating the driving reaction contingent on the coincident occurrence of an endergonic ("reverse") fluctuation in another thermodynamically weaker process, thereby creating a disequilibrium in that process.[13,151,152].

\section{Green rust - the first organizing nanoengine of life?}

Carbonate green rust $\left(\mathrm{GR}_{\mathrm{carb}}\right)$ nucleates rapidly to give a plethora of equi-dimensional planar micro- to nano-crysts generally measuring from $200 \mathrm{~nm}$ to $\sim 2 \mu \mathrm{m}$ across with a a relatively constant aspect ratio of $\sim 1: 10$.[153,154] So, a $1 \mu \mathrm{m} \mathrm{GR}_{\text {carb }}$ would be about $100 \mathrm{~nm}$ thick and comprise $\sim 130$ double layers overall.[154,155,156,157,158] The height of the hydroxyl interlayer galleries is $\sim 0.30 \mathrm{~nm}$, allowing them perhaps to act as anion and proton channels. And the $\mathrm{Fe}^{2+}-\mathrm{Fe}^{3+}$ distance of $\sim 0.33 \mathrm{~nm}$ along the iron layers would allow electron hopping by quantum tunneling, though a small proportion of electrons could also jump across the layers.[18,19] The brucite layers trap a monomolecular interlayer of viscous solution producing solutions concentrated to around 14 molar![7]

Green rust is redox active and can rapidly reduce nitrate to the ammonium ion as well as the redox sensitive ions such as $\mathrm{Mo}^{\mathrm{VI}}$ to $\mathrm{Mo}^{\mathrm{IV}}$. $[159,160,161,162,163,164,165,166,167,168,169]$ Such redox-sensitive trace metal ions tend to be reduced and precipitated from their soluble source at, and as, the outer edges of green rust are oxidized.[166] Moreover, such metastability would threaten the integrity of GRs were it not for their partially oxidized margins being highly attractive to orthophosphate $\left(\mathrm{HPO}_{4}{ }^{2-}\right)$. That the ionic diameter of the phosphate ion at $0.48 \mathrm{~nm}$ so exceeds those of the interlayer galleries at $\sim 0.3 \mathrm{~nm}$, causes it to block the GR margins and inhibit its oxidation.[170] However, it has been demonstrated that orthophosphate (Pi) can intercalate into hydrotalcite where it enforces a height of $0.37 \mathrm{~nm}$.[170.171] We speculate that protons ramming from the acidulous ocean would drive a portion of this phosphate into the hydrous interlayers of the green rust DLH. Once there, it could be forced to polymerize - the external proton gradient driving a strong pyrophosphate/orthophosphate (PPi:Pi) disequilibrium.[16,172] 
Phosphorylation of organic products of redox reactions involving carbon might then ensue.[16] The resulting gaps in the phosphate surrounds to the green rust will be instantly healed as more phosphate is attracted to the positively charged exterior.

To make green rust work as a thermodynamic engine to drive reductions, it would itself have to be continuously re-reduced. In this regard it has been demonstrated that green rust can also be reduced by hydrocarbons without degrading its structure, but whether methane could also reduce relatively oxidized green rust (via activation of NO) as we have suggested, must await experimental test.[54,173,174,175] Another possible, though undemonstrated, method would be the oxidation of hydrothermal hydrogen with nickel-dosed mackinawite or greigite, as in a Ni-Fe hydrogenase.[14,34,176,177] The resulting protons would be immediately neutralized by reaction with the hydroxyls in the alkaline hydrothermal flux. In other words, it is reasonable to assume that the redox states could be reversed (oscillate) depending on which way the disequilibria were stacked. Green rust has a low redox potential, being almost as reducing as native iron $\left(\mathrm{Fe}^{0}\right)$ in anoxic alkaline conditions.[178] Indeed, as we have noted, GRs can compete with biotic pathways in the reduction of, for example, selenate and nitrate.[160,179] Moreover, we have seen how green rust, with its well-ordered hydrous innards, can act as an aminase. For example, Barge and colleagues have also demonstrated the amination of pyruvate to alanine.[38]

There is an interdependence between the redox potential and the $\mathrm{pH}$ of green rusts: oxidation is promoted by deprotonation in alkaline conditions, while the reverse is true of acid conditions where protonation supports reduction.[17] These factors prompted Génin and his collaborators to remark, "Among all compounds containing FeII ions that can play the reservoir of reducing species, the FeII-III oxyhydroxysalts commonly denominated green rusts ... constitute an unmatchable compound due to their redox flexibility.[180] As might be expected, solid state reductions of oxidized green rusts can also be driven electrochemically, resulting again in a highly reduced but still morphologically recognizable double layer hydroxide $\left(\left[\mathrm{Fe}^{\mathrm{II}}{ }_{6}(\mathrm{OH})_{10}\right]\left[\mathrm{CO}_{3} .2 \mathrm{H}_{2} \mathrm{O}\right]\right)$ (Figure 2). [88,180] Nevertheless, without the protection of organic intercalates there is a tendency for the $\mathrm{Fe}^{2+}$ to dissolve, thereby threatening the integrity of the mineral.[20,125,182]

Although these green rust-comprising barriers would have been leaky, individual crystallites would have frustrated immediate dissipation.[28] Green rusts comprising this barrier would be subject to large redox and $\mathrm{pH}$ gradients with ranges that had the potential commensurate with that required for the onset of metabolism. Electrons could have been supplied from hydrothermal formate, hydrogen, or from oxyhydroxides and sulfides, dosed with other transition metals comprising the walls of hydrothermal chimneys, as they oxidize.[126,127,128,129,142] Redox oscillations may have oxidized and re-reduced iron ions between $\mathrm{Fe}^{2+}$ and $\mathrm{Fe}^{3+}$ much as our hemoglobin is cycled between 0 and 4 oxygens many times over as the red cells are pumped from lung to periphery and back with a cycling time of around 1 minute and with an average life span of 1,000 to 2,000 hours. At the same time the $\mathrm{pH}$ gradient would have contributed to protonation and deprotonation of green rust, tending to hold the mineral between the bounds of $2 \mathrm{Fe}^{2+} / \mathrm{Fe}^{3+}$ and $\mathrm{Fe}^{2+} / 2 \mathrm{Fe}^{3+}[167,183,184]$ The mineral so poised would have remained metastable, i.e., could have been party to an emergent homeostasis.[185] Such metastability may have been strongly supported by orthophosphate $\left(\mathrm{HPO}_{4}{ }^{2-}\right)$ which, having a larger ionic diameter of $0.48 \mathrm{~nm}$, tends to be adsorbed on the margins of green rust, and inhibits its oxidation.[170] As we have noted, Gustaf Arrhenius extolled the likely prebiotic virtues of the double layer hydroxides, saying "surface-active DLH minerals expand freely to accommodate molecular complexes of any size. These structures, thus, also serve as 
compartmental systems with flexible membranes and what may be called primitive cellular metabolic function. Like cells, they retain phosphate-charged reactants against high concentration gradients and exchange matter with the surroundings by controlled diffusion through the 'pores' provided by the opening of the interlayers at the crystal edges. Here, the exposed negative charge on the interrupted metal hydroxide 'membrane' leads to sorption of cations as "gatekeepers"'[7] He even goes on to speculate that the origin of information might lie in "the variable pattern of cations, conserved within individual (DLH) crystals," and further, that "such an animation process ... would be guided by the subtle electronic forces that metal cations exert on their environment," while opining "the progress so far in prebiotic chemistry merely suggests that it may be possible to synthesize the tape on which the information for life could be recorded, if we only knew how.'”[7]

The margins of green rust would be continually 'rammed' by hydronium ions from the $\sim 5$ $\mathrm{pH}$ ocean as the protons themselves were drawn down-gradient to the $\mathrm{pH} 11$ interior.[4] And their path would be vectored by the natural orientation of these layered minerals normal to the barrier's surfaces with the hydrous interlayers acting as channels.[117] And it may have been within the confines of green rust at high $\mathrm{pH}$ that condensation reactions could have been driven. Erastova and her collaborators - noting how mineral surfaces "may have very high enthalpies of rehydration" and thereby provide "a driving force for condensation reactions" - have suggested, through molecular dynamics simulations, how layered hydroxides can concentrate, align and act as adsorption templates for amino acids, and promote peptide bond formation.[186] Moreover, following Amend and Shock, Kitadai has found that - in regard to the thermodynamics of amino acid synthesis and polymerization - "hot, alkaline hydrothermal systems beneath cool, slightly acidic Hadean ocean are an energetically excellent setting among possible vent-ocean combinations".[187,188]

It might be argued that the water generated in these protobiochemical processes would tend to lyse any product. However, we argue that because the founding submarine alkaline mound was completely immersed in salty water both inside and out, bulk-water itself was minimized at the site of these and other reactions as a result of exosmosis from the hydrous interlayers (Figure 2).

\section{Iron sulfides: The supporting cast}

\subsection{Mackinawite [Fe(Ni,Mo)S]: Electron transfer agent, amino acid polymerase and possible hydrogenase}

Mackinawite has the extremely low redox potential of $-1,010 \mathrm{mV}$ at $\mathrm{pH} 12$ at $25^{\circ} \mathrm{C}$, lower even than green rust[189]. And $20 \%$ of the total iron in mackinawite can be oxidized before its layered conformation is lost and it converts to the water-absent inverse spinel, greigite $\left(\mathrm{Fe}_{3} \mathrm{~S}_{4}\right)$.[101,190] However, both nickel concentrations and the infusion of molecular $\mathrm{H}_{2}$ can inhibit this transition $[101,191,192,193]$ Indeed, up to $\sim 50 \%$ of the iron can be replaced by nickel without changing the mackinawite conformation although the solid solution is nonideal.[193] And Mo:Fe molar ratios in mackinawite precipitated in the presence of thiomolybdate, can reach $\sim 0.05$.[194] Both nickel and molybdenum are likely to promote catalytic activity.[103,195]

Unlike bound water in green rust, interlayer-water in mackinawite is only lightly bound and nanoconfinement of water greatly enhances its self-dissociation. This is because the effective 
viscosity therein is similar to that of bulk water - strongly favoring the rapid diffusion of excess protons by the Grotthuss mechanism $(116,117,172,196,197,198,199,200,201]$ Mackinawite is also known to be an excellent conductor, suggesting that electron-hopping along the iron layers in mackinawite could be coupled to proton transfer using intermolecular hydrogen-bonds through fluctuation and sequential H-bonding, as in peptides.[19,203] Such coupling of proton flux to electron flow, and vice-versa, would be comparable to the proton-coupled electron transfer (PCET) reduction of nitrite to NO reaction involving cytochrome $c d_{1}$ in nitrite reductase.[202,203,204,205,206] Indeed, we can imagine the aqueous interlayers within mackinawite acting as a proton wire with a rate of proton transfer over $25 \mathrm{~nm} \mathrm{~ns}^{-1}$ (about a tenth of the speed of sound) driven by a redox disequilibrium of $\sim 1 \mathrm{eV}$.[117, 200,207] Yet the hydroxyl ions (or proton holes) tend to be immobilized by hydrogen-bonding to sulfur and the dangling oxygen is partially hydrated, thus inhibiting the diffusion of hydroxyls through the galleries from the alkaline hydrothermal fluid, and thereby favoring proton transfer.[116].

Another biotic-like feature of these nano-confined conditions between the tetrahedral FeS sheets of mackinawite microcrysts is suggested by the 'nano-solvation' of glycine and its polymerization in the presence of carbonyl sulfide (Table 1).[116,199,208,209,210]

\subsection{Greigite $\left[\mathrm{Fe}_{3} \mathrm{~S}_{4}\right]$}

In the experimental growth of iron sulfide chimneys White and her colleagues found that mackinawite was partially oxidized to greigite $\left[\mathrm{Fe}^{2+} \mathrm{Fe}^{3+}{ }_{2} \mathrm{~S}_{4}\right]$ between $70^{\circ}$ and $75^{\circ} \mathrm{C}$.[101] We assume, after Rickard and Luther, that the reaction is autocatalytic with water as the oxidant.[213] The hydrogen produced in this reaction maybe occluded or trapped perhaps in the cuboidal entity of the greigite structure where it may be split, with electrons delocalized such that the average charge on the metals is decreased in the cuboid while the sulfides are protonated.[14] The sulfur atoms would remain in place during the transition, though the mackinawite $a$ axis is at a $45^{\circ}$ angle to that of greigite.[211] Microcrysts of greigite are magnetic and have low electrochemical resistance.[220,221,222] Greigite is an anhydrous inverse spinel wherein the apical iron (or nickel) is in the $2^{+}$state, while the delocalized electrons produce an average charge of $2.5^{+}$on the 4 iron ions in the cuboid.[212] Although the structure of greigite is afine with the active centers of ferredoxins (e.g., in molybdenum-bearing formate hydrogenlyase and radical SAM, and is comparable to the cuboids in the active centers of carbon monoxide dehydrogenase and acetyl coenzyme synthase, no passive 'catalytic' activity in these minerals has (yet) been demonstrated [28,122, 214, 215, 216,217,218,219]).

Nickel can deputize for iron in greigite, generally in $\sim \mathrm{Fe}_{5} \mathrm{NiS}_{8}$ or as violarite $\sim \mathrm{Fe}_{2} \mathrm{Ni}_{4} \mathrm{~S}_{8}$. $[33,212]$ Yamaguchi and coworkers have demonstrated the electrochemical reduction of carbon dioxide to formate and methane by coating a carbon paper electrode with violarite.[33] Efficiency, as we might expect, was substantially increased on addition of amine compounds.[33] Yet, in contrast to its occlusion in mackinawite, molybdenum appears to be excluded from the inverse spinel, though Ni-bearing greigite can be coated with layered $\mathrm{MoS}_{2}$ in the lab.[223] Dosed thus, Sharifvaghefi and Zheng show that it can, while remaining stable, promote both hydrogenation and desulfurization reactions of, for example, dibenzothiophene (DBT, $\left.\mathrm{H}_{4} \mathrm{C}_{6} \mathrm{~S} \mathrm{C}_{6} \mathrm{H}_{4}\right) \cdot[223]$

\subsection{Tochilinite $\mathrm{FeS}\left[\mathrm{Mg}, \mathrm{Fe}^{2+}\right][\mathrm{OH}]_{2}$}


We note here that though never identified as a precipitate in the AHV conditions, the mixed hydroxide and sulfide minerals tochilinite $\left(\mathrm{FeS}\left[\mathrm{Mg}, \mathrm{Fe}^{2+}\right][\mathrm{OH}]_{2}\right)$ and ferrotochilinite $\left(6 \mathrm{FeS} \cdot 5 \mathrm{Fe}(\mathrm{OH})_{2}\right)$ could also have been represented in the hydrothermal mound where it might have played a part in early metabolism.[224,225,226,227] These composite minerals comprise 6 mackinawite-like layers alternating with 5 brucite-like layers.[228] They can be grown below $200^{\circ} \mathrm{C}$ in alkaline hydrothermal solution, but as a result of the two-dimensional incommensurability of their sub-structures, they tend to curl into nanotubes.[229] Tochilinite occurs in serpentinized mafic and ultramafic rocks and in CM carbonaceous chondrites where it appears to result from moderate temperature hydrothermal alteration of olivine- and sulfide-rich precursors.[139,228,229,230,231,232,233]

\section{The peptide and amyloid takeover?}

Barge and her collaborators have demonstrated the amination of pyruvate to alanine in alkaline conditions within moderately reduced green rust.[38] Nevertheless, amino acids have not been polymerized in green rust or mackinawite to date. However, short peptides have been generated in conditions corresponding to the alkaline vent environment.[208,234] And once formed, even six-mer peptides spontaneously and promiscuously sequester inorganic $\mathrm{Fe}(\mathrm{Ni})$ sulfides, metal ions and pyrophosphate (PPi) clusters.[36,189,235,236,237,238,239] Such spontaneous folds around phosphate survive today as the GxxxxGKS/T motif of P-loop proteins.[240,241,242] The achiral glycines contribute the universal joints required for this coordination, generally referred to as the Walker motif, possibly a reminder of the emergence of an heterochiral world before the left-handed chirality of peptides became dominant?[243,244]

As it is the backbone amide hydrogen bonds that coordinate to the clusters, in these early times the side chains of amino acids played little part beyond, perhaps merely serving to bind two essential metal ions and orient substrates in the so-called "the two-metal-ion catalytic site"'.[35,189,245,246,247] The nesting itself renders the clusters more stable, more catalytically active and, in the case of the sulfides, significantly reduces their redox potential. These properties may have both quickened and directed the early evolution of metabolism. Indeed, these are the structures that were locked into many of the proteins of life as they evolved and complexified.

Many oligopeptides whose residues are sufficiently hydrophobic, will aggregate in water into so-called 'amyloid' fibrils. These structures stabilize the oligopeptides against proteolysis and can be capable of conformational self-replication. For example, oligopeptides comprising ala-ile-leu-ser-ser-thr pack as antiparallel beta-sheets that, in spite of having a dry hydrophobic core, can offer water-mediated interfaces, cf. the aquaporin channel.[238,248,249,250] Greenwald and Reik speculate that this was the common ancestor fold.[249] The sheets are capable of self-propagation, carrying information, and can be conformationally selfreplicating.[251,252,253,254] Amyloid has also been suggested by many as the likely first organic cell wall and membrane, favored over the leaky and inefficient iron mineral barriers.[238,255] Superior to lipids - which anyway are 'costly' to make, suffer the disadvantage of their impermeability, and likely evolved later - they maintain the capability of proto-enzymetic activity.[133,238,242,256,257]

\section{Ligand-assisted autocatalysis and 'Protoenzymes' (Table 1)}


5 to 6-mer alanine nests sequestering anionic clusters of the iron oxyhydroxides and sulfides, could also have played an essential role in mineral redox-powered disequilibriaconverting engines driving ligand-accelerated autocatalytic reactions. In this way geomechanochemical reactions could have been driven along the mineral-enabled pathways toward methanotrophy and acetogenesis, ever improving as peptides sequester active clusters, eventuating in an incomplete reverse tricarboxylic acid cycle before biochemistry took over proper. Table 1 indicates the possible steps in the putative ligand accelerated pathway to life's emergence, and Figure 1 details the possible transition from the earth to the life sciences.

\section{Emergence of life as a biofilm}

We have suggested here that amyloid-forming peptides would be the first organic polymers to be produced within the interlayers of green rust and that these would be secreted to envelop their layered iron mineral parents (Figure 2). We further speculate that pods of amyloidbearing nanocrysts and peptide nests may have differentiated to protocells of a common size dictated by water content and binding forces. Such cells may have developed different functions, perhaps forming a symbiotic cooperative. In this scenario we might imagine that the intercellular spaces being occupied by amyloid would bind the individual proto-cells together to give individuated cellular cooperatives.[28,258] Thus, the first palpable living communities, still at the hydrothermal mound, could have been biofilms, adherence then, as it is often now, provided by 'excess' amyloid, probably augmented with carboxylates.[259,260,261,262,263,264,265,266] These putative biofilms comprising 'minimal organic cells' may have resembled iron-bearing microbialites.[267]

\section{Discussion of method and approach}

We began this article with a quote from Leduc as a basis for the quest to understand life's emergence.[1] We quote him again here to give context for this 'unending' quest - to remind us that some provisional explanation is required for the emergence of life to give root to the Darwinian program.[177,268] Leduc insists that "The chain of life is of necessity a continuous one, from the mineral at one end to the most complicated organism at the other. We cannot allow that it is broken at any point, or that there is a link missing between animate and inanimate nature (viz. the missing link between the inorganic and the organic kingdoms). Hence the theory of evolution necessarily admits the physico-chemical nature of life and the fact of spontaneous generation. Only thus can the evolutionary theory become a rational one, a stimulating and fertile inspirer of research."[1] Or more bluntly "Without the idea of spontaneous generation and a physical theory of life, the doctrine of evolution is a mutilated hypothesis without unity or cohesion.’[1]

Darwin was certainly conscious of the need to understand life's emergence to provide the root for his evolutionary tree but considered the issue beyond the confines of science as it then was.[269] Indeed, in a letter to Hooker in 1863 he let go with "Who would have ever thought of the old stupid Athenæum taking to Oken-like transcendental philosophy written in Owenian style! It will be some time before we see "slime, snot or protoplasm" (what an elegant writer) generating a new animal [Owen]. But I have long regretted that I truckled to public opinion \& used the Pentateuchal term of creation, by which I really meant "appeared" by some wholly 
unknown process. It is mere rubbish thinking, at present, of origin of life; one might as well think of origin of matter" (https://www.darwinproject.ac.uk/letter/DCP-LETT-4065.xml).

It is often overlooked that Darwin's approach was steeped in the geological milieu he shared with his mentors, Adam Sedgwick and Charles Lyell, two of the founders of modern geology. Indeed, he was a self-proclaimed geologist himself, so it is all the more surprising that earth science is given such short shrift by chemists who rarely consider the initial conditions offered to them by geology.[270,271] Just to report experiments that happen to work in the lab, that seem to mimic certain of life's pathways, but using unverifiable, indeed, implausible, prebiotic ferrocyanide 'feedstocks', leads us to wander into a miasma of uncertainties. It is time to reflect on Polanyi's premonition: "it is only when we are confronted with the anxious dilemma of a live scientific issue, that the ambiguity of the formal processes and of various attenuated criteria of scientific truth becomes apparent, and leaves us without effective guidance.[272] In other words, we have to think widely and beyond our disciplinary boundaries!

It is true that the notion of 'spontaneous generation' had fallen into disfavor, where it still resides, since Pasteur's famous experiment, and Darwin himself sought to distance himself from the idea.[273] Indeed, Deane Butcher recounts how Pasteur's acolytes prevented publication of Leduc's hypotheses for some time in France - hypotheses that remain disparaged even in this new century.[1,274] However, it should be remembered that the phrase tends to be understood to support a system supplied with the 'organic building blocks of life', whereas Leduc's notion assumed the spontaneous generation to have been in an inorganic milieu.[1] The AHV theory reiterated here also assumes a spontaneous inorganic emergence of life - a theory yet considered as inconsistent with advances made in the laboratory.[275] But again, this is to misunderstand how completely new knowledge is come by.[276] The outcomes of theory and experiments should lead toward palpable goals. In this regard the AHV theory did predict the presence of offridge submarine alkaline vents in the present oceans, a prognosis met by the discovery of the Lost City submarine alkaline vents in 2000.[5,12,277] It also explains, for example, why early life did not have to invent such a counterintuitive mechanism as that entailed in Mitchell's proton motive force, how it was supplied with the necessary low entropy C1 feed, how biosynthesis could proceed in a highly radiated and neutral atmosphere, and why it wasn't anyway destroyed by surface catastrophes in the Hadean. Here we not only list experiments favoring the theory overlooked by, for example, Ritson and his coworkers, but detail further predictions, some of which could be falsified, reveal embarrassing missing links or even leave the AHVT as just one more casualty of the general theory of 'natural rejection'! (Table 1).[275,278]. In Feynman's exacting dictum, here "we are trying to prove ourselves wrong as quickly as possible, because only in that way can we find progress".[279]

\section{Conclusions}

The purpose of this contribution is to suggest how the submarine alkaline hydrothermal vent model could be subjected to stringent tests that would indicate its failure, or partial failure, to provide a path forward in emergence-of-life researches. The suggestions detailed in Figure 1 and Table 1, built on some empirical evidence, assume that the $\sim 150$ or so hydrous interlayers of green rust, clamped between layered pliable redox-active iron hydroxide boundaries dosed with $\mathrm{Ni}$, Co and Mo and supported by iron sulfides, provide the potential to: i) differentiate and specialize functions such as proton-pumping and thereby the generation of a far-out-ofequilibrium PPi:Pi ratio, ii) enable electron bifurcation, iii) reduce $\mathrm{CO}_{2}$ to formate or carbon 
monoxide, iv) oxidize hydrogen and methane to methyl groups to react with formate or $\mathrm{CO}$ and thereby, v) produce acetate and pyruvate, vi) reduce nitrate, vii) aminate carboxylic acids to the simple amino acids, viii) polymerize these to heterochiral peptides to protect the evolving system at its various scales - all-in-all resulting in the germination and first flowering of the organic evolutionary tree as it emerges from the hydroponically-fertilized green rust seed. The activity of the water generated in these proto-biosynthetic reactions may have been kept low in the hydrous innards of green rust and mackinawite through exosmosis to the salty surrounds.[93,186]

The AHV theory as it stands, focuses on how the hydrous interlayers or channels in green rust, and to a lesser degree in mackinawite, likely mediated the imposed proton gradient and, through the bifurcation of electron pairs, effectively stepped up the redox gradients to the effect of driving an organic takeover.[4] We are conscious that the relative contributions of green rust, mackinawite and associated minerals, and how they may have cooperated in Leduc's 'synthetic biology', has been left unresolved. And we alert the reader to a significant revision of the AHV theory since its first proposal, namely that although we still recognize that the job of life overall is to hydrogenate carbon dioxide, it may be that life first captured both the partially and fully reduced forms of $\mathrm{C} 1$ carbon as hydrothermal formate and methane, and only later (though well before LUCA) 'learnt' to reduce $\mathrm{CO}_{2}$ through all the required intermediates for $\mathrm{CO}_{2}$ autotrophy to emerge from its mineral placenta.[50,54,55]

At bottom is the assumption that the protonically and electronically powered nanoengines and disequilibrium conversions needed to drive those endergonic reactions required to produce life's many processors and its superstructures today were initially coopted from iron oxyhydroxides and sulfides, dosed with transition metals and phosphate, precipitated at the submarine alkaline vent.[13,280,281,282] However, even in the light of some experimental support we can see no clear path to the nucleotide world and, beyond intriguing suggestions of Greenwell and Coveney and others, the theory dissipates in hypotheses, ideas and speculation.[7,34,283] Nevertheless, "that living organisms are distinguished, not by their momentary appearance, but by their behaviour and by their relationship to their environment" in Mitchell's memorable phrase, would also be true for the putative layered hydrated seed crystals to life.[284]

So, maybe it all began with the selection of thermodynamically-driven microcrysts which could 'improve' (increase the system's dissipative flow) by becoming more organized and complicated, and/or by growing or declining in 'size', and/or by replicating, and, in doing any or all of these the more efficiently, they could have 'captured' the driving disequilibria, to the effect of converting those disequilibria ever faster and more efficiently on the path to subjugation by the organic world. But showing how selection for the 'fittest' in this sense can happen, or does happen, in the mineral precipitates is the major challenge?[3,4,55,177]

\section{Acknowledgements}

I thank Elbert Branscomb, Wolfgang Nitschke, Grayson Chadwick, Laurie Barge, Stuart Bartlett, Julyan Cartwright, Leon Alkali, Jan Arends, Patrick Beckett, Isik Kanik, Adrian Ponce and Adrian Stoica for discussions. I am also grateful to two anonymous referees ' for their generous suggestions and corrections. This research was supported by NASA, through the NASA Astrobiology Institute under cooperative agreement issued through the Science Mission directorate; No. NNH13ZDA017C (Icy Worlds) at the Jet Propulsion Laboratory and the Jet Propulsion Laboratory Blue Sky Thinktank (California, USA). 


\section{Conflicts of Interest}

The author declares no conflict of interest.

\section{References}

1. Leduc, S. The Mechanism of Life, Rebman Ltd., London, 1911.

2. Korenaga, J.; Planavsky, N.J.; Evans, D.A. Global water cycle and the coevolution of the Earth's interior and surface environment. Phil. Trans. R. Soc. A 2017, 375, 20150393.

3. Branscomb, E.; Russell, M.J. Frankenstein or a submarine alkaline vent: Who is responsible for abiogenesis? Part 1: What is life-that it might create itself? BioEssays 2018, 40, 700179.

4. Branscomb, E.; Russell, M.J. Frankenstein or a submarine alkaline vent: Who is responsible for abiogenesis? Part 2: As life is now, so it must have been in the beginning. BioEssays 2018, 40, 700182.

5. Russell, M.J.; Hall, A.J.; Turner, D. In vitro growth of iron sulphide chimneys: possible culture chambers for origin-of-life experiments. Terra Nova 1989, 1, 238-241.

6. Branscomb, E.; Russell, M.J. Turnstiles and bifurcators: the disequilibrium converting engines that put metabolism on the road. Biochim. Biophys. Acta 2013, 1827, 62-78.

7. Arrhenius, G.O. Crystals and life. Helv. Chim. Acta. 2003, 86, 1569-1586.

8. Allmann, R. Doppelschichtstrukturen mit brucitähnlichen Schichtionen [Me(II) $)_{1-}$ $\left.{ }_{\mathrm{x}} \mathrm{Me}(\mathrm{III})_{\mathrm{x}}(\mathrm{OH})_{2}\right]^{\mathrm{x}+}$. Chimia 1970, 24, 99-108.

9. Allmann, R. Das Bindungsprinzip der Doppelschichtstrukturen mit brucitähnlichen Schichtionen. Fortschr. Miner. 1971, 48, 24-30.

10. Okumura, T.; Ohara, Y.; Stern, R.J.; Yamanaka, T.; Onishi, Y.; Watanabe, H.; Chen, C.; Bloomer, S.H.; Pujana, I.; Sakai, S.; Ishii, T. Brucite chimney formation and carbonate alteration at the Shinkai Seep Field, a serpentinite-hosted vent system in the southern Mariana forearc. Geochem. Geophys. Geosyst. 2016, 17, 3775-3796.

11. Pisapia, C.; Gérard, E.; Gérard, M.; Lecourt, L.; Lang, S.Q.; Pelletier, B.; Payri, C.E.; Monnin, C.; Guentas, L.; Postec, A.; Quéméneur, M. Mineralizing filamentous bacteria from the Prony Bay Hydrothermal Field give new insights into the functioning of serpentinizationbased subseafloor ecosystems. Front. Microbio. 2017, 57.

12. Kelley, D.S.; Karson, J.A.; Blackman, D.K.; Früh-Green, G.L.; Butterfield, D.A.,; Lilley, M.D.; Olson, E.J.; Schrenk, M.O.; Roe, K.K.; Lebon, G.T.; Rivizzigno, P.; and the AT3-60 Shipboard Party. An off-axis hydrothermal vent field near the Mid-Atlantic Ridge at $30^{\circ} \mathrm{N}$. Nature 2001, 412, 145-149.

13. Branscomb, E.; Biancalani, T.; Goldenfeld, N.; Russell, M.J. Escapement mechanisms and the conversion of disequilibria: The engines of creation. Phys. Rep. 2017, 677, 1-6.

14. Russell, M.J.; Hall, A.J. 2006, The onset and early evolution of life. In Kesler, S.E., and Ohmoto, H., eds., Evolution of Early Earth's Atmosphere, Hydrosphere, and BiosphereConstraints from Ore Deposits, Geol. Soc. Am. Mem. 2006, 198, 1-32.

15. Nitschke, W.; Russell, M.J. Hydrothermal focusing of chemical and chemiosmotic energy, supported by delivery of catalytic Fe, Ni, Mo/W, Co, S and Se, forced life to emerge. J. Mol. Evol. 2009, 69, 481-496.

16. Russell, M.J.; Nitschke, W.; Branscomb, E. The inevitable journey to being. Phil. Trans. $R$. Soc. Lond. B. Biol. Sci. 2013, 368, 20120254. 
17. Génin, J.-M.R.; Aïssa, R.; Géhin, A.; Abdelmoula, M.; Benali, O.; Ernstsen, V.; OnaNguema, G.; Upadhyay, C.; Ruby, C. Fougerite and Fe ${ }^{\mathrm{II}-\mathrm{III}}$ hydroxycarbonate green rust; ordering, deprotonation and/or cation substitution; structure of hydrotalcite-like compounds and mythic ferrosic hydroxide $\mathrm{Fe}(\mathrm{OH})_{(2+\mathrm{x})}$. Solid State Sci. 2005, 7, 545-572.

18. Wander, M.C.; Rosso, K.M.; Schoonen, M.A. Structure and charge hopping dynamics in green rust. J. Phys. Chem. C 2007, 111, 11414-11423.

19. Page, C.C.; Moser, C.C.; Chen, X; Dutton, P.L. Natural engineering principles of electron tunnelling in biological oxidation-reduction. Nature 1999, 402, 47-52

20. Russell, M.J.; Daniel, R.M.; Hall, A.J.; Sherringham, J. A hydrothermally precipitated catalytic iron sulphide membrane as a first step toward life. J. Mol. Evol. 1994, 39, 231-243.

21. Mitchell, P. Keilin's respiratory chain concept and its chemiosmotic consequences. Science 1979, 206, 1148-1159.

22. Herschy, B.; Whicher, A.; Camprubi, E.; Watson, C.; Dartnell, L.; Ward, J.; Evans, J.R.; Lane, N. An origin-of-life reactor to simulate alkaline hydrothermal vents. J. Mol. Evol. 2014, 79, 213-227.

23. Ljungdahl, L.G.; Irion, E.; Wood, H.G. Total synthesis of acetate from $\mathrm{CO}_{2}$. I. Comethylcobyric acid and co-(methyl)-5-methoxy-benzimidizolycobamide as intermediates with Clostridium thermoaceticum. Biochem. 1965, 4, 2771-2779.

24. Fuchs, G. Alternative pathways of autotrophic $\mathrm{CO}_{2}$ fixation. In Autotrophic Bacteria, Eds H.G. Schlegel and B. Bowen, Science Technology, Madison, WI, 1989, 365-382.

25. Fuchs, G. Alternative pathways of carbon dioxide fixation: insights into the early evolution of life. Annu. Rev. Microbiol. 2011, 65, 631-658.

26. Ragsdale, S.W. The Eastern and Western branches of the Wood/Ljungdahl pathway: how the East and West were won. BioFactors 1997, 6, 3-11.

27. Russell, M.J.; Martin, W. The rocky roots of the acetyl coenzyme-A pathway. TIBS, 2004, 24, 358-363.

28. Russell, M.J.; Hall, A.J. The emergence of life from iron monosulphide bubbles at a submarine hydrothermal redox and pH front. J. Geol. Soc. 1997, 154, 377-402.

29. Windman, T.; Zolotova, N.; Schwandner, F.; Shock, E.L. Formate as an energy source for microbial metabolism in chemosynthetic zones of hydrothermal ecosystems. Astrobiology 2007, 7, 873-890.

30. Sojo, V.; Herschy, B.; Whicher, A.; Camprubi, E.; Lane, N. The origin of life in alkaline hydrothermal vents. Astrobiology, 2016, 16, 181-197.

31. Marchand, C.; Le Calve, S.; Mirabel, P.; Glasser, N.; Casset, A.; Schneider, N.; De Blay, F. Concentrations and determinants of gaseous aldehydes in 162 homes in Strasbourg (France). Atmos. Environ. 2008, 42, 505-516.

32. Jiang, C.; Zhang, P. Indoor carbonyl compounds in an academic building in Beijing, China: concentrations and influencing factors. Front. Environ. Sci. Eng. 2012, 6, 184-194.

33. Yamaguchi, A.; Yamamoto, M.; Takai, K.; Ishii, T.; Hashimoto, K.; Nakamura, R. Electrochemical $\mathrm{CO}_{2}$ reduction by Ni-containing iron sulfides: How is $\mathrm{CO}_{2}$ electrochemically reduced at bisulfide-bearing deep-sea hydrothermal precipitates? Electrochim. Acta 2014, 141, 311-318.

34. Russell, M.J.; Hall, A.J.; Mellersh, A.R. On the dissipation of thermal and chemical energies on the early Earth: The onsets of hydrothermal convection, chemiosmosis, genetically regulated metabolism and oxygenic photosynthesis. In Natural and Laboratory-Simulated 
Thermal Geochemical Processes, R. Ikan ed. Dordrecht, Kluwer Academic Publishers 2003, 325-388.

35. Milner-White, E.J.; Russell, M.J. Nests as sites for phosphates and iron-sulfur thiolates in the first membranes: 3 to 6 residue anion-binding motifs (nests). Orig. Life Evol. Biosph. 2005, $35,19-27$.

36. Milner-White, E.J.; Russell, M.J. Functional capabilities of the earliest peptides and the emergence of life. Genes 2011, 2, 671-688.

37. Falkowski, P.G.; Fenchel, T.; Delong, E.F. The microbial engines that drive Earth's biogeochemical cycles. Science 2008, 320, 1034-1039.

38. Flores, E.; Barge, L.; VanderVelde, D.; Kallas, K.; Baum, M.M.; Russell, M.J., Kanik, I. Amino acid synthesis in seafloor environments on icy worlds. Am. Astron. Soc. DPS Meeting 2016, 48, id.323.02.

39. Bungs, M.; Tributsch, H. Electrochemical and photoelectrochemical insertion and transport of hydrogen in pyrite, Ber. Bunsenges. Phys. Chem. 1997, 101, 1844.

40. Russell, M.J.; Hall, A.J.; Fallick, A.E.; Boyce, A.J. On hydrothermal convection systems and the emergence of life. Econ. Geol. 2005, 100, 419-438.

41. Huber, C.; Wächtershäuser, G. Primordial reductive amination revisited. Tetrahedron Letters, 2003, 44, 1695-1697.

42. Huber, C.; Wächtershäuser, G. Activated acetic acid by carbon fixation on (Fe,Ni)S under primordial conditions. Science 1997, 276, 245-247.

43. Heinz, W.; Lauwers, A.M. Organic sulfur compounds resulting from the interaction of iron sulfide, hydrogen sulfide and carbon dioxide in an anaerobic aqueous environment. Orig. Life Evol. Biosph. 1996, 26, 131-150.

44. Heinen, W.; Lauwers, A. The iron-sulfur world and the origins of life: abiotic thiol synthesis from metallic iron, $\mathrm{H}_{2} \mathrm{~S}$ and $\mathrm{CO}_{2}$; a comparison of the thiol generating $\mathrm{FeS} / \mathrm{HCl}\left(\mathrm{H}_{2} \mathrm{~S}\right) / \mathrm{CO}_{2}-$ system and its $\mathrm{Fe}^{0} / \mathrm{H}_{2} \mathrm{~S} / \mathrm{CO}_{2}$-counterpart. Proc. Koninklijke Nederlandse Akademie van Wetenschappen, Amsterdam 1997, 100, 11-25.

45. Mielke, R.E.; Russell, M.J.; Wilson, P.R.; McGlynn, S.; Coleman, M.; Kidd, R.; Kanik, I., Design, fabrication and test of a hydrothermal reactor for origin-of-life experiments, Astrobiology 2010, 10, 799-810.

46. Shibuya, T.; Yoshizaki, M.; Masaki, Y.; Suzuki, K.; Takai, K.; Russell, M.J. Reactions between basalt and $\mathrm{CO}_{2}$-rich seawater at 250 and $350^{\circ} \mathrm{C}, 500$ bars: Implications for the $\mathrm{CO}_{2}$ sequestration into the modern oceanic crust and the composition of hydrothermal vent fluid in the $\mathrm{CO}_{2}$-rich early ocean. Chem. Geol. 2013, 359, 1-9.

47. Shibuya, T.; Russell, M.J.; Takai, K. Free energy distribution and hydrothermal mineral precipitation in Hadean submarine alkaline vent systems; Importance of iron redox reactions under anoxic conditions. Geochim. Cosmochim. Acta. 2016, 175, 1-19.

48. Reeves, E.P.; McDermott, J.M.; Seewald, J.S. The origin of methanethiol in midocean ridge hydrothermal fluids. Proc. Natl. Acad. Sci. USA 2014, 111, 5474-5479.

49. Goldschmidt, V.M. Geochemical aspects of the origin of complex organic molecules on Earth, as precursors to organic life. New Biol. 1952, 12, 97-105.

50. Say, R.F.; Fuchs, G. Fructose 1,6-bisphosphate aldolase/phosphatase may be an ancestral gluconeogenic enzyme. Nature 2010, 464, 1077-1081.

51 Proskurowski, G.; Lilley, M.D.; Seewald, J.S.; Früh-Green, G.L.; Olson, E.J.; Lupton, J.E.; Sylva, S.P.; Kelley, D.S. Abiogenic hydrocarbon production at Lost City hydrothermal field. Science 2008, 319, 604-607. 
52. Shock, E.L. Geochemical constraints on the origin of organic compounds in hydrothermal systems. Orig. Life Evol. Biosph. 1990, 20, 331-367.

53. Williams, R.J.P.; Frausto da Silva, J.J.R. The natural selection of the chemical elements. 1996, Clarendon. Oxford.

54. Nitschke, W.; Russell, M.J. Beating the acetyl coenzyme-A pathway to the origin of life. Phil. Trans. R. Soc. Lond. B. Biol. Sci. 2013, 368, 20120.

55. Russell, M.J.; Nitschke, W. Methane: Fuel or exhaust at the emergence of life. Astrobiology 2017, 17, 1053-1066.

56. Nealson, K. H.; Belz, A.; McKee, B. Breathing metals as a way of life: geobiology in action. Antonie Leeuwenhoek Int. J. Gen. Mol. Microbiol. 2002, 81, 215-222.

57. Ducluzeau, A-L.; van Lis, R.; Duval, S.; Schoepp-Cothenet, B.; Russell, M.J.; Nitschke, W. Was nitric oxide the first strongly oxidizing terminal electron sink? TIBS 2009, 34, 9-15.

58. Wong, M.L.; Charnay, B.D.; Gao, P.; Yung, Y. L.; Russell, M.J. Nitrogen oxides in early Earth's atmosphere as electron acceptors for life's emergence. Astrobiology 2017, 17, 975983.

59. Bounama, C.; Franck, S.; von Bloh, W. The fate of the Earth's ocean. Hydro. Earth Syst. Sci. 2001, 5, 569-575.

60. Mojzsis, S.J.; Harrison, T.M.; Pidgeon, R.T. Oxygen-isotope evidence from ancient zircons for liquid water at the Earth's surface 4,300 Myr ago. Nature 2001, 409, 178-181.

61. Valley, J.W.; Lackey, J.S.; Cavosie, A.J.; Clechenko, C.C.; Spicuzza, M.J.; Basei, M.A.S.; Bindeman, I.N.; Ferreira, V.P.; Sial, A.N.; King, E.M.; Peck, W.H. 4.4 billion years of crustal maturation: oxygen isotope ratios of magmatic zircon. Contr. Mineral Petrol. 2005, 150, 561-580.

62. Bédard, J.H. A catalytic delamination-driven model for coupled genesis of Archaean crust and sub-continental lithospheric mantle. Geochim. Cosmochim. Acta. 2006. 70, 1188-1214.

63. Bédard, J.H. Stagnant lids and mantle overturns: implications for Archaean tectonics, magmagenesis, crustal growth, mantle evolution, and the start of plate tectonics. Geosci. Front. 2018, 9, 19-49.

64. Zahnle, K.; Arndt, N.; Cockell, C.; Halliday, A.; Nisbet, E.; Selsis, F.; Sleep, N.H. Emergence of a habitable planet. Space Sci. Rev. 2007, 129, 35-78.

65. Greenwood, R.C.; Barrat, J.A.; Miller, M.F.; Anand, M.; Dauphas, N.; Franchi, I.A.; Sillard, P.; Starkey, N.A. Oxygen isotopic evidence for accretion of Earth's water before a highenergy Moon-forming giant impact. Sci. Adv. 2018, 4, eaao5928.

66. Beall, A. P.; Moresi, L.; Cooper, C.M. Formation of cratonic lithosphere during the initiation of plate tectonics. Geology 2018, 46, 487-490.

67. Daly, R.T.; Schultz, P.H. The delivery of water by impacts from planetary accretion to present. Sci. $A d v$. 2018, 4, eaar2632.

68. Mann, P.; Taira, A. Global tectonic significance of the Solomon Islands and Ontong Java Plateau convergent zone. Tectonophys. 2004, 389, 137-190.

69. Roberge, J.; Wallace, P.J.; White, R.V.; Coffin, M.F. (2005). Anomalous uplift and subsidence of the Ontong Java Plateau inferred from $\mathrm{CO}_{2}$ contents of submarine basaltic glasses. Geology 2005, 33, 501-504.

70. Abramov, O.; Mojzsis, S.J. Microbial habitability of the Hadean Earth during the Late Heavy Bombardment. Nature, 2009, 459, 419-422. 
71. Jackson, M.G.; Cabral, R.A.; Rose-Koga, E.F.; Koga, K.T.; Price, A.; Hauri, E. H.; Michael, P. Ultra-depleted melts in olivine-hosted melt inclusions from the Ontong Java Plateau. Chem. Geol. 2015, 414, 124-137.

72. Moore, W.B.; Webb, A.A.G. Heat-pipe earth. Nature 2013, 501, 501-505.

73. O’Neil, J.; Boyet, M.; Carlson, R.W.; Paquette, J-L.; Half a billion years of reworking of Hadean mafic crust to produce the Nuvvuagittuq Eoarchean felsic crust. Earth Planet. Sci. Lett. 2013, 379, 13-25.

74. Fisher, C.M.; Vervoort, J.D. Using the magmatic record to constrain the growth of continental crust-The Eoarchean zircon Hf record of Greenland. Earth Planet. Sci. Lett. 2008, 488, 79-91.

75. Zharkov, V.N. On the history of the lunar orbit. Astron. Vesn. 2000, 34, 1-11.

76. Pinti, D.L. The origin and evolution of the oceans. In Lectures in astrobiology, Springer, Berlin, Heidelberg, 2005, 83-112.

77. Vallée, Y.; Shalayel, I.; Ly, K.D.; Rao, K.R.; De Paëpe, G.; Märker, K.; Milet, A. At the very beginning of life on Earth: the thiol-rich peptide (TRP) world hypothesis. Int. J. Devel. Biol. 2017, 61, 471-478.

78. Shapiro, R. Astrobiology: Life's beginnings. Nature 2011, 476, 30.

79. Van Kranendonk, M.J. Two types of Archean continental crust: Plume and plate tectonics on early Earth. Am. J. Sci. 2010, 310, 1187-1209.

80. Kamber, B.S. The evolving nature of terrestrial crust from the Hadean, through the Archaean, into the Proterozoic. Precam. Res. 2015, 258, 48-82.

81. Gourcerol, B.; Thurston, P.C., Kontak, D.J.; Côté-Mantha, O.; Biczok, J. Distinguishing primary and mineralization-related signatures of chert from the banded iron-formation-hosted gold deposits at Musselwhite, Ontario and Meadowbank, Nunavut. Geol. Surv. Can. 2015, 1, $1-24$.

82. Kump, L.R.; Seyfried, W.E. Hydrothermal Fe fluxes during the Precambrian: effect of low oceanic sulfate concentrations and low hydrostatic pressure on the composition of black smokers. Earth Planet. Sci. Lett. 2005, 235, 654-662.

83. Gäb, F.; Ballhaus, C.; Siemens, J.; Heuser, A.; Lissner, M.; Geisler, T.; Garbe-Schönberg, D. Siderite cannot be used as $\mathrm{CO}_{2}$ sensor for Archaean atmospheres. Geochim. Cosmochim. Acta. 2017, 214, 209-225.

84. Kusakabe, M.; Tanyileke, G.Z.; McCord, S.A.; Schladow, S.G. Recent pH and $\mathrm{CO}_{2}$ profiles at Lakes Nyos and Monoun, Cameroon: implications for the degassing strategy and its numerical simulation. J. Volc. Geotherm. Res. 2000, 97, 241-260.

85. Macleod, G.; McKeown, C.; Hall, A.J.; Russell, M.J. Hydrothermal and oceanic ph conditions of possible relevance to the origin of life. Orig. Life Evol. Biosph. 1994, 24, 1941.

86. Bernal, J.D.; Dasgupta, D.R.; Mackay, A.L. The oxides and hydroxides of iron and their structural inter-relationships. Clay Miner. Bull. 1959, 4, 15-30.

87. Isley, A.E.; Abbott, D.H. Plume-related mafic volcanism and the deposition of banded iron formation. J. Geophys. Res. Solid Earth 1999, 104(B7), 15461-15477.

88. Antony, H.; Legrand, L.; Chaussé, A. Carbonate and sulphate green rusts - mechanisms of oxidation and reduction. Electrochim. Acta, 2008, 53, 7146-7156.

89. Tosca, N.J.; Guggenheim, S.; Pufahl, P.K. An authigenic origin for Precambrian greenalite: Implications for iron formation and the chemistry of ancient seawater. Geol. Soc. Am. Bull. 2016, 128, 511-530. 
90. Halevy, I.; Alesker, M.; Schuster, E.M.; Popovitz-Biro, R.; Feldman, Y. A key role for green rust in the Precambrian oceans and the genesis of iron formations. Nature Geosci. 2017, 10, 135-139.

91. Russell, M.J.; Hall, A.J.; Martin, W. Serpentinization and its contribution to the energy for the emergence of life. Geobiology 2010, 8, 355-371.

92. Russell, M.J. Life is a verb, not a noun. Geology 2017, 45, 1143-1144

93. Russell, M.J.; Barge, L.M.; Bhartia, R.; Bocanegra, D.; Bracher, P.J.; Branscomb, E.; Kidd, R.; McGlynn, S.E.; Meier, D.H.; Nitschke, W.; Shibuya, T.; Vance, S.; White, L.; Kanik, I. The drive to life on wet and icy worlds. Astrobiology 2014, 14, 308-343.

94. Appel, P.W.U. Mineral occurrences in the 3.6 Ga old Isua supracrustal belt, West Greenland. Develop. Precamb. Geol. 1990, 8, 593-603.

95. Appel, P.W.U. On the early Archaean Isua iron-formation, west Greenland. Precamb. Res. 1980, 11, 73-87.

96. Gole, M.J. Mineralogy and petrology of very-low-metamorphic grade Archaean banded ironformations, Weld Range, Western Australia. Am. Mineral. 1980, 65, 8-25.

97. Kuma, K.; Paplawsky, W.; Gedulin, B.; Arrhenius, G. Mixed-valence hydroxides as bioorganic host minerals. Orig. Life Evol. Biosph. 1989, 19, 573-601.

98. Arrhenius, G.; Gedulin, B.; Mojzsis, S. Phosphate in models for chemical evolution. In Chemical Evolution and Origin of Life, C. Ponnamperuma, J. Chela-Flores, Eds. Harpers Brothers, New York, 1993, 23-40.

99. Russell, M.J.; Hall, A.J., A hydrothermal source of energy and materials at the origin of life. In Chemical Evolution II: From Origins of Life to Modern Society, American Chemical Society, 2009, 45-62.

100. Klein, C. Some Precambrian banded iron-formations (BIFs) from around the world: Their age, geologic setting, mineralogy, metamorphism, geochemistry, and origins. Am. Mineral. 2005, 90, 1473-1499.

101. White, L.M.; Bhartia, R.; Stucky, G.D.; Kanik, I.; Russell, M.J. Mackinawite and greigite in ancient alkaline hydrothermal chimneys: Identifying potential key catalysts for emergent life. Earth Planet. Sci. Lett. 2015, 430, 105-114.

102. Sun, S.; Li, Y.L. Geneses and evolutions of iron-bearing minerals in banded iron formations of $>3760$ to ca. 2200 million-year-old: Constraints from electron microscopic, X-ray diffraction and Mössbauer spectroscopic investigations. Precamb. Res. 2017, 289, 1-17.

103 Li, Y.; Yamaguchi, A.; Yamamoto, M.; Takai, K.; Nakamura, R. Molybdenum sulfide: A bioinspired electrocatalyst for dissimilatory ammonia synthesis with geoelectrical current. $J$. Phys. Chem. C 2016, 121, 2154-2164.

104. Ball, P. Water as an active constituent in cell biology. Chem. Rev. 2008, 108, 74-108.

105. Szent-Györgyi, A. Bioelectronics. Science 1968, 161, 988-990.

106. Fischer, S.; Verma, C.S. Binding of buried structural water increases the flexibility of proteins. Proc. Natl. Acad. Sci. USA 1999, 96, 9613-9615.

107. Frauenfelder, H.; Chen, G.; Berendzen, J.; Fenimore, P.W.; Jansson, H.; McMahon, B.H.; Stroe, I.R.; Swenson, J.; Young, R.D.. A unified model of protein dynamics. Proc. Natl. Acad. Sci. USA 2009, 106, 5129-5134.

108. Jungwirth, P. Biological water or rather water in biology? J. Phys. Chem. Lett. 2015, 6, 2449-2451

109. Mentré, P. Water in the orchestration of the cell machinery. Some misunderstandings: a short review. J. Biol. Phys. 2012, 38, 13-26. 
110. Pattee, H.H. The nature of hierarchical controls in living matter. Found. Math. Biol. 1972, $1,1-22$.

111. Helgeson, H.C.; Delany, J.M.; Nesbitt, H.W.; Bird, D.K. Summary and critique of the thermodynamic properties of rock-forming minerals. Am. J. Sci. 1978, 278, 1-229.

112. Westheimer, F.H. Why nature chose phosphates. Science 1987, 235, 1173-1178.

113. Dunitz, J.D. The entropic cost of bound water in crystals and biomolecules. Science 1994, 264, 670-671.

114. Dzade, N.Y.; Roldan, A.; de Leeuw, N.H. Structures and properties of $\mathrm{As}(\mathrm{OH})_{3}$ adsorption complexes on hydrated mackinawite (FeS) surfaces: A DFT-D2 study. Environ. Sci. Tech. 2017, 51, 3461-3470.

115. Dorvee, J.R.; Veis, A. Water in the formation of biogenic minerals: peeling away the hydration layers. J. Struct. Biol. 2013, 183, 278-303.

116. Muñoz-Santiburcio, D.; Marx, D. Nanoconfinement in slit pores enhances water selfdissociation. Phys. Rev. Lett. 2017, 119, 056002.

117. Xu, J.; Voth, G.A. Computer simulation of explicit proton translocation in cytochrome c oxidase: the D-pathway. Proc. Natl. Acad. Sci. USA 2005, 102, 6795-6800.

118. Chang, C.J.; Chng, L.L.; Nocera, D.G. Proton-coupled O-O activation on a redox platform bearing a hydrogen-bonding scaffold. JACS 2003, 125, 1866-1876.

119. Rosenzweig, A.C.; Frederick, C.A.; Lippard, S.J.; Nordlund, P. Crystal structure of a bacterial non-haem iron hydroxylase that catalyses the biological oxidation of methane. Nature 1993, 366, 537-543.

120. Hsiao, C.; Williams, L.D. A recurrent magnesium-binding motif provides a framework for the ribosomal peptidyl transferase center. Nucleic Acids Res. 2009, 37, 3134-3142.

121. Bai, L.; Wagner, T.; Xu, T.; Hu, X.; Ermler, U.; Shima, S. Water-bridged H-bonding network contributes to the catalysis of a SAM-dependent C-methyltransferase HcgC. Angew. Chem. Int. Ed. 2017, 10.1002/anie.201705605.

122. Baymann, F.; Lebrun, E.; Brugna, M.; Schoepp-Cothenet, B.; Giudici-Orticoni, M.-T.; Nitschke, W. The redox protein construction kit; pre-LUCA evolution of energy conserving enzymes. Phil. Trans. R. Soc. Lond. B 2003, 358, 267-274.

123. Nitschke, W.; Russell, M.J., Redox bifurcations; how they work and what they mean to extant life and (potentially) to its inorganic roots. BioEssays 2011, 34, 106-109.

124. Mielke, R.E.; Robinson, K.J.; White, L.M.; McGlynn, S.E.; McEachern, K.; Bhartia, R.; Kanik, I.; Russell, M.J., Iron-sulfide-bearing chimneys as potential catalytic energy traps at life's emergence. Astrobiology, 201, 11, 933-950.

125. McGlynn, S.E.; Kanik, I.; Russell, M.J. Peptide and RNA contributions to iron-sulphur chemical gardens as life's first inorganic compartments, catalysts, capacitors and condensers. Phil. Trans. R. Soc. A 2012, 370, 3007-3022.

126. Nakamura, R.; Takashima, T.; Kato, S.; Takai, K., Yamamoto, M.; Hashimoto, K. Electrical current generation across a black smoker chimney. Angew. Chem. Int. Ed. 2010, 49, 76927694.

127. Yamamoto, M.; Nakamura, R.; Oguri, K.; Kawagucci, S.; Suzuki, K.; Hashimoto, K.; Takai, K. Generation of electricity and illumination by an environmental fuel cell in deepsea hydrothermal vents. Angew. Chem. Int. Ed. 2013, 52, 10758-10761.

128. Yamamoto, M.; Nakamura, R.; Kasaya, T.; Kumagai, H.; Suzuki, K.; Takai, K. Spontaneous and widespread electricity generation in natural deep-sea hydrothermal fields. Angew. Chem. Int. Ed. 2017, 56, 5725-5728. 
129. Barge, L.M.; Abedian, Y.; Russell, M.J.; Doloboff, I.J.; Cartwright, J.H.; Kidd, R.D. Kanik, I. From chemical gardens to fuel cells: Generation of electrical potential and current across self-assembling iron mineral membranes. Angew. Chem. Int. Ed. 2015, 54, 8184-8187.

130. Ferris, F.G.; Jack, T.R.; Bramhill, B.J. Corrosion products associated with attached bacteria at an oil field water injection plant. Can. J. Microbiol. 1992, 38, 1320-1324.

131. Maden, B.E.H. Tetrahydrofolate and tetrahydromethanopterin compared: functionally distinct carriers in C1 metabolism. Biochem. J. 2000, 350, 609-629.

132. Buckel, W.; Thauer, R.K. Flavin-based electron bifurcation, ferredoxin, flavodoxin, and anaerobic respiration with protons $(\mathrm{Ech})$ or $\mathrm{NAD}^{+}(\mathrm{Rnf})$ as electron acceptors: A historical review. Front. Microbial. 2018, 9, 401.

133. Martin, W.; Russell M.J. On the origin of biochemistry at an alkaline hydrothermal vent. Phil. Trans. Roy. Soc. London B: Biol. Sci. 2007, 362, 1887-1925

134. Ragsdale, S.W.; Pierce, E. Acetogenesis and the Wood-Ljungdahl pathway of $\mathrm{CO}_{2}$ fixation. Biochim. Biophys. Acta 2008, 1784, 1873-1898.

135. Herrmann, G., Jayamani, E., Mai, G.; Buckel, W. Energy conservation via electrontransferring flavoprotein in anaerobic bacteria. J. Bact. 2008, 190, 784-791.

136. Martin, W.; Baross, J.; Kelley, D.; Russell, M. J. Hydrothermal vents and the origin of life. Nature Rev. Microbiol. 2008, 6, 805-814.

137. Tsai, J.Y.; Kellosalo, J.; Sun, Y.J.; Goldman, A. Proton/sodium pumping pyrophosphatases: the last of the primary ion pumps. Curr. Op. Struct. Biol. 2014, 27, 3847.

138. Yoshida, M.; Muneyuki, E.; Hisabori, T. ATP synthase - a marvellous rotary engine of the cell. Nature Rev. Mol. Cell Biol. 2001, 2, 669-677.

139. Alt J.C.; Shanks W.C. Serpentinization of abyssal peridotites from the MARK area, MidAtlantic Ridge: Sulfur geochemistry and reaction modeling. Geochim. Cosmochim. Acta 2003, 67, 641-653.

140. Kelley, D.S.; Karson, J.A.; Früh-Green, G.L.; Yoerger, D.R.; Shank, T.M.; Butterfield, D.A.; Hayes, J.M.; Schrenk, M.O.; Olson, E.J.; Proskurowski, G.; Jakuba, M.; Bradley, A.; Larson, B.; Ludwig, K.; Glickson, D.; Buckman, K.; Bradley, A.S.; Brazelton, W.J.; Roe, K.; Elend, M.J.; Delacour, A.; Bernasconi, S.M.; Lilley, M.D.; Baross, J.A.; Summons, R.E.; Sylva, S.P. A serpentinite-hosted ecosystem: the Lost City hydrothermal field. Science 2005, 307, 1428-1434.

141. Lang, S.Q.; Butterfield, D.A.; Schulte, M.; Kelley, D.S.; Lilley, M.D. Elevated concentrations of formate, acetate and dissolved organic carbon found at the Lost City hydrothermal field. Geochim. Cosmochim. Acta 2010, 74, 941-952.

142. Windman, T.; Zolotova, N.; Schwandner, F.; Shock, E.L. Formate as an energy source for microbial metabolism in chemosynthetic zones of hydrothermal ecosystems. Astrobiology 2007, 7, 873-890.

143. Williams, A.C.; Ramsden, D.B. Hydrogen symbioses in evolution and disease. Q. J. Med. 2007, 100, 451-459.

144. Beratan, D.N., Liu, C.; Migliore, A.; Polizzi, N.F.; Skourtis, S.S.; Zhang, P.; Zhang, Y. Charge transfer in dynamical biosystems, or the treachery of (static) images. Acc. Chem. Res. 2014, 48, 474-481.

145. Allen, D.E.; Seyfried, W.E. Serpentinization and heat generation: constraints from Lost City and Rainbow hydrothermal systems. Geochim. Cosmochim. Acta 2004, 68, 1347-1354. 
146 Makarieva, A.M.; Gorshkov, V.G., Li, B.L. Energetics of the smallest: do bacteria breathe at the same rate as whales?. Proc. Roy. Soc. London B: Biol. Sci. 2005, 272, 2219-2224.

147. LaRowe, D.E.; Amend, J.P. Catabolic rates, population sizes and doubling/replacement times of microorganisms in natural settings. Am. J. Sci. 2015, 315, 167-203.

148 Cottrell, A. The natural philosophy of engines, Contemp. Phys. 1979, 20, 1-10.

149 Sigurdsson, H.; Devine, J.D.; Tchua, F.M.; Presser, F.M.; Pringle, M.K.W.; Evans, W.C. Origin of the lethal gas burst from Lake Monoun, Cameroun. J. Volc. Geotherm. Res. 1987, 31, 1-16.

150 Schoepp-Cothenet, B.; Van Lis, R.; Atteia, A.; Baymann, F.; Capowiez, L.; Ducluzeau, A.L.; Duval, S.; Ten Brink, F.; Russell, M.J.; Nitschke, W. 2013. On the universal core of bioenergetics. Biochim. Biophys. Acta 2013, 1827, 79-93.

151. Seifert, U. Stochastic thermodynamics, fluctuation theorems, and molecular machines. Rep. Progr. Phys. 2012, 75,126001.

152. Caplan, S.; Essig, A. Bioenergetics and Linear Nonequilibrium Thermodynamics; The Steady State, Harvard Univ., 1999.

153. Géhin, A.; Ruby, C.; Abdelmoula, M.; Benali, O.; Ghanbaja, J.; Refait, P.; Genin, J.M.R. Synthesis of Fe (II-III) hydroxysulphate green rust by coprecipitation. Solid State Sci. 2002, 4, 61-66.

154. Christiansen, B.C.; Balic-Zunic, T.; Petit, P.O.; Frandsen, C.; Mørup, S.; Geckeis, H.; Katerinopoulou, A.; Stipp, S.S. Composition and structure of an iron-bearing, layered double hydroxide (LDH)-green rust sodium sulphate. Geochim. Cosmochim. Acta, 2009, 73, 3579-3592.

155. Khan, A.I.; O'Hare, D. Intercalation chemistry of layered double hydroxides: recent developments and applications. J. Mat. Chem, 2002, 12, 3191-3198.

156. Braterman, P.S.; Xu, Z.P.; Yarberry, F. Layered double hydroxides (LDHs). Handbook of Layered Materials 2004, 373-474.

157. Génin, J.M.R.; Ruby, C. Anion and cation distributions in Fe (II-III) hydroxysalt green rusts from XRD and Mössbauer analysis (carbonate, chloride, sulphate,...); the "fougerite" mineral. Solid State Sci. 2004, 6, 705-718.

158. Thyveetil, M.A.; Coveney, P.V.; Greenwell, H.C.; Suter, J.L. Role of host layer flexibility in DNA guest intercalation revealed by computer simulation of layered nanomaterials. JACS 2008, 130, 12485-12495.

159. Hugot-LeáGoff, A. Localized corrosion processes in iron and steels studied by in situ Raman spectroscopy. Faraday Disc. 1992, 94, 137-147.

160. Hansen, H.C.B.; Koch, C.B.; Nancke-Krogh, H.; Borggaard, O.K.; Sørensen, J. Abiotic nitrate reduction to ammonium: key role of green rust. Environ. Sci. Technol. 1996, 30, 2053-2056.

161. Hansen H.C.B.; Gulberg S.; Erbs M.; Koch C.B. Kinetics of nitrate reduction by green rusts: effects of interlayer anion and Fe(II): Fe(III) ratio. Appl. Clay Sci. 2001, 18, 81-91.

162. Ottley, C.J.; Davison, W.; Edmunds, W.M. Chemical catalysis of nitrate reduction by iron (II). Geochim. Cosmochim. Acta 1997, 61, 1819-1828.

163. Kolb, V.; Zhang, S.; Xu, Y.; Arrhenius, G. Mineral induced phosphorylation of glycolate ion-a metaphor in chemical evolution. Orig. Life Evol. Biosph. 1997, 27, 485-503.

164. Hansen, H.C.B.; Koch, C.B. Reduction of nitrate to ammonium by sulphate green rust: activation energy and reaction mechanism. Clay Min. 1998, 33, 87-101. 
165. Loyaux-Lawniczak, S.; Refait, P.; Ehrhardt, J-J.; Lecomte, P.; Génin. J-M.R. Trapping of $\mathrm{Cr}$ by formation of ferrihydrite during the reduction of chromate ions by Fe (II)-Fe (III) hydroxysalt green rusts. Environ. Sci. Tech. 2000, 34, 438-443.

166. O’Loughlin, E.J.; Kelly, S.D.; Cook, R.E.; Csencsits, R.; Kemner, K.M. Reduction of uranium(VI) by mixed iron(II/iron(III) hydroxide (green rust): Formation of $\mathrm{UO}_{2}$ nanoparticles. Environ. Sci. Technol. 2003, 37, 721-727.

167. Génin, J.M.; Mills, S.J.; Christy, A G.; Guérin, O.; Herbillon, A.J.; Kuzmann, E.; OnaNguema, G.; Ruby, C.; Upadhyay, C. Mössbauerite, $\mathrm{Fe}^{3+}{ }_{6} \mathrm{O}_{4}(\mathrm{OH})_{8}\left[\mathrm{CO}_{3}\right] \cdot 3 \mathrm{H}_{2} \mathrm{O}$, the fully oxidized 'green rust' mineral from Mont Saint-Michel Bay, France. Mineralog. Mag. 2014, $78,447-465$.

168. Trolard, F.; Bourrié, G. Structure of fougerite and green rusts and a thermodynamic model for their stabilities. J. Geochem. Expl. 2006, 88, 249-251.

169. Omwoma, S.; Chen, W.; Tsunashima, R.; Song, Y.F. Recent advances on polyoxometalates intercalated layered double hydroxides: From synthetic approaches to functional material applications. Coord. Chem. Rev. 2014, 258, 58-71.

170. O'Loughlin, E.J.; Gorski, C.A.; Scherer, M.M. Effects of phosphate on secondary mineral formation during the bioreduction of akaganeite $(\beta-\mathrm{FeOOH})$ : Green rust versus framboidal magnetite. Curr. Inorg. Chem. 2015, 5, 214-224.

171. Ookubo, A.; Ooi, K.; Hayashi, H. Preparation and phosphate ion-exchange properties of a hydrotalcite-like compound. Langmuir 1993, 9, 1418-1422.

172 Dass, A.V.; Jaber, M.; Brack, A.; Foucher, F.; Kee, T.P.; Georgelin, T.; Westall, F. Potential role of inorganic confined environments in prebiotic phosphorylation. Life. 2018, 8, 7.

173. Sabot, R.; Jeannin, M.; Gadouleau, M.; Guo, Q.; Sicre, E.; Refait, P. Influence of lactate ions on the formation of rust. Corros. Sci. 2007, 49, 1610-1624.

174. Sumoondur, A. D.; Shaw, S.; Benning, L.G. Formation of lactate intercalated Green Rust via the reductive dissolution of ferrihydrite. Geochim. Cosmochim. Acta 2009, 73, A1291.

175. Ayala-Luis, K.B.; Koch, C.B.; Hansen, H.C.B. Intercalation of linear C9-C16 carboxylates in layered FeII-FeIII-hydroxides (green rust) via ion exchange. Appl. Clay Sci. 2010, 48, 334-341.

176. McGlynn, S.E.; Mulder, D.W.; Shepard, E.M.; Broderick, J.B.; Peters, J.W. Hydrogenase cluster biosynthesis: organometallic chemistry nature's way. Dalton Trans. 2009, 22, 42744285.

177. Nath, I.; Chakraborty, J.; Verpoort, F. Metal organic frameworks mimicking natural enzymes: a structural and functional analogy. Chem. Soc. Rev. 2016, 45, 4127-4170.

178. Trolard, F.; Bourrié, G. Fougerite a natural layered double hydroxide in gley soil: habitus, structure, and some properties. In Clay Minerals in Nature: Their Characterization, Modification and Application, M. Valaskova, G.S. Martynkova, Eds. InTech, Rijeka, Croatia, 2012, 171-188.

179. Myneni, S.C.B.; Tokunaga, T.K.; Brown, G.E. Abiotic selenium redox transformations in the presence of Fe (II, III) oxides. Science 1997, 278, 1106-1109.

180. Génin, J.-M.R., Renard, A. and Ruby, C. Fougérite FeII-III oxyhydroxycarbonate in environmental chemistry and nitrate reduction. Hyperfine Interactions 2008, 186, 31-37.

181. Barge, L.M., Abedian, Y., Doloboff, I.J., Nuñez, J.E., Russell, M.J., Kidd, R.D., Kanik, I. Chemical gardens as flow-through reactors simulating natural hydrothermal systems. JoVE 2014, 105,53015 . 
182. Yin, W.; Huang, L.; Pedersen, E.B.; Frandsen, C.; Hansen, H.C.B. Glycine buffered synthesis of layered iron (II)-iron (III) hydroxides (green rusts). Journal of colloid and interface science, 2017, 497, 429-438.

183. Génin, J.M.R.; Ruby, C.; Upadhyay, C. Structure and thermodynamics of ferrous, stoichiometric and ferric oxyhydroxycarbonate green rusts; redox flexibility and fougerite mineral. Solid state Sci 2006, 8, 1330-1343.

184. Mills, S.J.; Christy, A.G.; Génin, J.M.; Kameda, T.; Colombo, F. (). Nomenclature of the hydrotalcite supergroup: natural layered double hydroxides. Mineralog. Mag. 2012, 76, 1289-1336.

185. Turner, J.S. Homeostasis and the physiological dimension of niche construction theory in ecology and evolution. Evol. Ecol. 2016, 30, 203-219.

186. Erastova, V.; Degiacomi, M.T.; Fraser, D.G.; Greenwell, H.C. Mineral surface chemistry control for origin of prebiotic peptides. Nature Commun. 2017, 8, 2033.

187. Amend, J.P.; Shock, E.L. Energetics of amino acid synthesis in hydrothermal ecosystems. Science 1998, 281, 1659-1662

188. Kitadai, N. Energetics of amino acid synthesis in alkaline hydrothermal environments. Orig. Life Evol. Biosph. 2015, 45, 377-409.

189. Kim, J. D.; Rodriguez-Granillo, A.; Case, D.A.; Nanda, V.; Falkowsk, P.G. Energetic selection of topology in ferredoxins. PLoS computational biology 2012, 8, e1002463.

190. Mullet, M.; Boursiquot, S.; Abdelmoula, M.; Génin, J.M.; Ehrhardt, J.J. Surface chemistry and structural properties of mackinawite prepared by reaction of sulfide ions with metallic iron. Geochim. Cosmochim. Acta 2002, 66, 829-836.

191. Benning, L.G.; Wilkin, R.T.; Barnes, H.L. Reaction pathways in the Fe-S system below $100^{\circ}$ C. Chem. Geol. 2000, 167, 25-51.

192. Rickard, D.; Butler, I.B.; Oldroyd, A. A novel iron sulphide mineral switch and its implications for Earth and planetary science. Earth Planet. Sci. Lett. 2001, 189, 85-91.

193. Wilkin, R.T.; Beak, D.G. Uptake of nickel by synthetic mackinawite. Chem. Geol. 2017, 462, 15-29.

194. Helz, G.R.; Vorlicek, T.P.; Kahn, M.D. Molybdenum scavenging by iron monosulfide. Environ. Sci. Tech. 2004, 38, 4263-4268.

195. McKone, J.R.; Marinescu, S.C.; Brunschwig, B.S.; Winkler, J.R.; Gray, H.B. Earthabundant hydrogen evolution electrocatalysts. Chem. Sci. 2014, 5, 865-878.

196. Agmon, N. The grotthuss mechanism. Chem. Phys. Lett. 1995, 244, 456-462.

197. Cukierman, S. Et tu, Grotthuss! and other unfinished stories. Biochim. Biophys. Acta 2006, 1757, 876-885.

198. Marx, D.; Chandra, A.; Tuckerman, M.E. Aqueous basic solutions: hydroxide solvation, structural diffusion, and comparison to the hydrated proton. Chem. Rev. 2010, 110, 21742216.

199. Muñoz-Santiburcio, D.; Marx, D. Chemistry in nanoconfined water. Chem. Sci. 2017, 8,

200. Muñoz-Santiburcio, D.; Wittekindt, C.; Marx, D. Nanoconfinement effects on hydrated excess protons in layered materials. Nature Commun. 2013, 4, doi:10.1038/ncomms3349.

201. Terranova, U.; de Leeuw, N.H. A force field for mackinawite surface simulations in an aqueous environment. Theor. Chem. Acc. 2016, 135, 46.

202. Tadokoro, M.; Hosoda, H.; Inoue, T.; Murayama, A.; Noguchi, K.; Iioka, A.; Nishimura, R.; Itoh, M.; Sugaya, T.; Kamebuchi, H.; Haga, M.A. Synchronized collective proton- 
assisted electron transfer in solid state by hydrogen-bonding $\mathrm{Ru}$ (II)/Ru (III) mixed-valence molecular crystals. Inorg. Chem. 2017, 56, 8513-8526.

203. Yu, X.; Lovrincic, R.; Sepunaru, L.; Li, W.; Vilan, A.; Pecht, I.; Sheves, M.; Cahen, D.. Insights into solid-state electron transport through proteins from inelastic tunneling spectroscopy: The case of azurin. ACS nano 2015, 9, 9955-9963.

204. Strous, M.; Pelletier, E.; Mangenot, S.; Rattei, T.; Lehner, A.; Taylor, M.W.; Horn, M.; Daims, H.; Bartol-Mavel, D.; Wincker, P.; Barbe, V. Deciphering the evolution and metabolism of an anammox bacterium from a community genome. Nature 2006, 440, 790794.

205. Kaila, V. R. I.; Verkhovsky, M. I.; Wikström, M. Proton-coupled electron transfer in cytochrome oxidase. Chem. Rev. 2010, 110, 7062-7081.

206. Li, M.; Ford, T.; Li, X.; Gu, J.D. Cytochrome cd1-containing nitrite reductase encoding gene nirS as a new functional biomarker for detection of anaerobic ammonium oxidizing (Anammox) bacteria. Environ. Sci. Tech. 2011, 45, 3547-3553.

207. Wraight, C.A. Chance and design—proton transfer in water, channels and bioenergetic proteins. Biochim. Biophys. Acta 2006, 1757, 886-912.

208. Huber, C.; Wächtershäuser, G. Peptides by activation of amino acids with $\mathrm{CO}$ on (Ni,Fe)S surfaces: implications for the origin of life. Science 1998, 281, 670-671.

209. Huber, C.; Eisenreich, W.; Hecht, S.; Wächtershäuser, G. A possible primordial peptide cycle. Science 2003, 301, 938-940.

210. Leman, L.; Orgel, L.; Ghadiri, M.R. Carbonyl sulfide-mediated prebiotic formation of peptides. Science, 2004, 306, 283-286.

211. Lennie, A R.; Redfern, S.A.; Champness, P.E.; Stoddart, C.P.; Schofield, P.F.; Vaughan, D.J. Transformation of mackinawite to greigite: An in situ X-ray powder diffraction and transmission electron microscope study. Am. Mineral. 1997, 82, 302-309.

212. Vaughan, D.J.; Craig, J.R. The crystal chemistry of iron-nickel thiospinels. Am. Mineral. 1985, 70, 1036-1043.

213. Rickard, D.; Luther, G.W. Chemistry of iron sulfides. Chem. Rev. 2007, 107, 514-562.

214. Andrews, S.C.; Berks, B.C.; McClay, J.; Ambler, A.; Quail, M.A.; Golby, P.; Guest, J.R. A 12-cistron Escherichia coli operon (hyf) encoding a putative proton-translocating formate hydrogenlyase system. Microbiol. 1997, 143, 3633-3647.

215. Beinert, H.; Holm, R.H.; Münck, E. Iron-sulfur clusters: nature's modular, multipurpose structures. Science 1997, 277, 653-659.

216. Walsby, C.J.; Hong, W.; Broderick, W.E.; Cheek, J.; Ortillo, D.; Broderick, J.B.; Hoffman, B.M. Electron-nuclear double resonance spectroscopic evidence that S-adenosylmethionine binds in contact with the catalytically active $[4 \mathrm{Fe}-4 \mathrm{~S}]^{+}$cluster of pyruvate formate-lyase activating enzyme. JACS 2002, 124, 3143-3151.

217. Buis, J.M.; Broderick, J.B. Pyruvate formate-lyase activating enzyme: Elucidation of a novel mechanism for glycyl radical formation. Arch. Biochem. Biophys. 2005, 433, 288-296.

218. Mehta, A.P.; Abdelwahed, S.H.; Mahanta, N.; Fedoseyenko, D.; Philmus, B.; Cooper, L.E.; Liu, Y.; Jhulki, I.; Ealick, S.E.; Begley, T.P. Radical S-adenosylmethionine (SAM) enzymes in cofactor biosynthesis: a treasure trove of complex organic radical rearrangement reactions. J. Biol. Chem. 2015, 290, 3980-3986.

219. Nitschke, W.; McGlynn, S.E.; Milner-White, E.J.; Russell, M.J. On the antiquity of metalloenzymes and their substrates in bioenergetics. Biochim. Biophys. Acta 2013, 1827, 871-881. 
220. Mitra-Delmotte, G.; Mitra, A. Magnetism, entropy, and the first nano-machines. Open Physics, 2010, 8, 259-272.

221. Li, G.; Zhang, B.; Yu, F.; Novakova, A.A.; Krivenkov, M.S.; Kiseleva, T.Y.; Chang, L.; Rao, J.; Polyakov, A.O.; Blake, G.R.; de Groot, R.A. High-purity $\mathrm{Fe}_{3} \mathrm{~S}_{4}$ greigite microcrystals for magnetic and electrochemical performance. Chem. Mat. 2014, 26, 58215829.

222. Li, T.; Li, H.; Wu, Z.; Hao, H.; Liu, J.; Huang, T.; Sun, H.; Zhang, J.; Zhang, H.; Guo, Z. Colloidal synthesis of greigite nanoplates with controlled lateral size for electrochemical applications. Nanoscale 2015, 7, 4171-4178.

223. Sharifvaghefi, S.; Zheng, Y. Dispersed Ni and Co promoted $\mathrm{MoS}_{2}$ catalysts with magnetic greigite as a core: Performance and stability in hydrodesulfurization. Chem. Select 2017, 2, 4678-4685.

224. Zolensky, M.E.; Mackinnon, I.D. Microstructures of cylindrical tochilinites. Am. Mineral. 1986, 71, 1201-1209.

225. Beard, J.S. Occurrence and composition of tochilinite and related minerals in Site 1068 serpentinites. In Proceedings of the Ocean Drilling Program Scientific Results, Vol. 173, M.O. Beslier, R.B. Whitmarsh, P.J. Wallace, J. Girardeau, Eds. Ocean Drilling Program, College Station, TX, 2000, 1-9.

226. Anthony, J.W.; Bideaux, R.A.; Bladh, K.W.; Nichols, M.C. Handbook of Mineralogy; Mineralogical Society of America: Chantilly, VA, 2003; Vols. I-V.

227. Pekov, I.V.; Sereda, E.V.; Polekhovsky, Y.S.; Britvin, S.N.; Chukanov, N.V.; Yapaskurt, V.O; Bryzgalov, I.A. Ferrotochilinite, $6 \mathrm{FeS} \cdot 5 \mathrm{Fe}(\mathrm{OH})_{2}$, a new mineral from the Oktyabr'sky deposit, Noril'sk district, Siberia, Russia. Geology of Ore Deposits 2013, 55, 567-574.

228. Butt, C.R.M.; Nickel, E.H. Mineralogy and geochemistry of the weathering of the disseminated nickel sulfide deposit at Mt. Keith, Western Australia. Econ. Geol. 1981, 76, 1736-1751.

229. Peng, Y.; Xu, L.; Xi, G.; Zhong, C.; Lu, J.; Meng, Z.; Li, G.; Zhang, S.; Zhang, G.; Qian, Y. An experimental study on the hydrothermal preparation of tochilinite nanotubes and tochilinite-serpentine-intergrowth nanotubes from metal particles. Geochim. Cosmochim. Acta 2007, 71, 2858-2875.

230. Tomeoka, K.; Buseck, P.R. A new layered mineral from the Mighei carbonaceous chondrite. Nature 1983, 306, 354-356.

231. Tomeoka, K.; Buseck, P.R. Indicators of aqueous alteration in CM carbonaceous chondrites: Microtextures of a layered mineral containing Fe, S, O and Ni. Geochim. Cosmochim. Acta 1985, 49, 2149-2163.

232. Matsubara, S.; Kato, A. Tochilinite in ultrabasic rock from Kurotani, Gifu Prefecture, central Japan. Bull. Nat. Sci. Mus. Tokyo, Ser. C, 1992, 18, 117-120.

233. Zolensky, M.E. Hydrothermal alternation of CM carbonaceous chondrites: implications of the identification of tochilinite as one type of meteoritic PCP. Meteoritics 1984, 19, 346347.

234. Huber, C.; Wächtershäuser, G Primordial reductive amination revisited: Tetrahed. Lett. 2003, 44, 1695-1697.

235. Martin, R.B.; Chamberlin, M.; Edsal, J.T. The association of nickel(II) ion with peptides. JACS 1960, 82, 495-498.

236. Ma, N.W.H.; White, D.A.; Martin, R.B. Metal ion exchange of square-planar nickel(II) tetraglycine with polydentate amines. Inorg. Chem. 1967, 6, 1632-1636. 
237. Alipázaga, M.V.; Lowinsohn, D.; Bertotti, M.; Coichev, N. Sulfite induced autoxidationof $\mathrm{Ni}(\mathrm{II})$ and $\mathrm{Co}(\mathrm{II})$ tetraglycine complexes. Spectrophotometric and rotating ring-disc voltammetric studies. Dalton Trans. 2004, 267-272.

238. Milner-White, E.J.; Russell, M.J. Predicting peptide and protein conformations in early evolution. Biol. Direct 2008, 3.

239. Bianchi, A.; Giorgi, C.; Ruzza, P.; Toniolo, C.; Milner-White, E.J. A synthetic hexapeptide designed to resemble a proteinaceous P-loop nest is shown to bind inorganic phosphate. Proteins: Struct. Funct. Bioinform. 2012, 80, 1418-1424.

240. Baltscheffsky, M.; Schultz, A.; Baltscheffsky, H. H+-PPases: a tightly membrane-bound family. FEBS Lett. 1999, 457, 527-533.

241 Watson, J.D.; Milner-White, E.J. A novel main-chain anion-binding site in proteins: The nest. A particular combination of phi,psi values in successive residues gives rise to anionbinding sites that occur commonly and are found often at functionally important regions. $J$. Mol. Biol. 2002, 315, 171-182.

242. Hayward, S.; Leader, D.P.; Al-Shubailly, F.; Milner-White, E.J. Rings and ribbons in protein structures: Characterization using helical parameters and Ramachandran plots for repeating dipeptides. Proteins: Struct. Funct. Bioinform 2014, 82, 230-239.

243 Walker, J.E.; Saraste, M.; Runswick, M.J.; Gay, N.J. Distantly related sequences in the $\boldsymbol{\alpha}$ and $\boldsymbol{\beta}$-subunits of ATP synthase, myosin, kinases and other ATP requiring enzymes and a common nucleotide binding fold. EMBO J. 1982, 1, 945-951.

244. Carny, O; Gazit, E. Creating prebiotic sanctuary: Self-assembling supramolecular peptide structures bind and stabilize RNA. Orig. Life Evol. Biosph. 2011, 41, 121-132.

245. Freemont, P.S.; Friedman, J.M.; Beese, L.S.; Sanderson, M.R.; Steitz, T.A. Cocrystal structure of an editing complex of Klenow fragment with DNA. Proc. Natl. Acad. Sci. USA 1988, 85, 8924-8928.

246. Steitz, T.A.; Steitz, J.A. A general two-metal-ion mechanism for catalytic RNA. Proc. Natl. Acad. Sci. USA 1993, 90, 6498-6502.

247. Nanda, V.; Senn, S.; Pike, D.H.; Rodriguez-Granillo, A.; Hansen, W.A.; Khare, S.D., Noy, D. Structural principles for computational and de novo design of $4 \mathrm{Fe}-4 \mathrm{~S}$ metalloproteins. Biochim. Biophys. Acta 2016, 1857, 531-538.

248. Kurland, C.G. The RNA dreamtime: Modern cells feature proteins that might have supported a prebiotic polypeptide world but nothing indicates that RNA world ever was. Bioessays 2010, 32, 866-871.

249. Greenwald, J.; Riek, R. On the possible amyloid origin of protein folds. J. Mol. Biol. 2012, 421, 417-426.

250. Eisenberg, D.S.; Sawaya, M.R. Structural studies of amyloid proteins at the molecular level. Ann. Rev. Biochem. 2017, 86, 69-95.

251. Takahashi, Y.; Mihara, H. Construction of a chemically and conformationally selfreplicating system of amyloid-like fibrils. Bioorg. Med. Chem. 2004, 12, 693-699.

252. Maury, C.P.J. Self-propagating $\beta$-sheet polypeptide structures as prebiotic informational molecular entities: the amyloid world. Orig. Life Evol. Biosph. 2009, 39, 141-150.

253. Wiltzius, J.J.; Landau, M.; Nelson, R.; Sawaya, M.R.; Apostol, M.I.; Goldschmidt, L.; Soriaga, A.B.; Cascio, D.; Rajashankar, K.; Eisenberg, D., Molecular mechanisms for protein-encoded inheritance. Nature Struct. Mol. Biol. 2009, 16, 973. 
254. Kang, S.G.; Huynh, T.; Xia, Z.; Zhang, Y.; Fang, H.; Wei, G.; Zhou, R. Hydrophobic interaction drives surface-assisted epitaxial assembly of amyloid-like peptides. JACS 2013, 135, 3150-3157.

255. Zhang, S.; Holmes, T.; Lockshin, C.; Rich, A. Spontaneous assembly of a selfcomplementary oligopeptide to form a stable macroscopic membrane. Proc. Natl. Acad. Sci. USA 1993, 90, 3334-3338.

256. Rufo, C.M.; Moroz, Y.S.; Moroz, O.V.; Stöhr, J.; Smith, T.A.; Hu, X.; DeGrado, W.F.; Korendovych, I.V. Short peptides self-assemble to produce catalytic amyloids. Nature Chem. 2014, 6, 303-309.

257. Dalai, P.; Ustriyana, P.; Sahai, N. Aqueous magnesium as an environmental selection pressure in the evolution of phospholipid membranes on early earth. Geochim. Cosmochim. Acta. 2018, 223, 216-228.

258. Russell, M.J.; Daia, D.E; Hall, A.J.. The emergence of life from FeS bubbles at alkaline hot springs in an acid ocean. In: Thermophiles: The keys to molecular evolution and the origin of life? J. Wiegel, M.W. Adams, Eds, Taylor and Francis, London and Philadelphia, 1998, 77-126.

259. Chernoff, Y.O. Amyloidogenic domains, prions and structural inheritance: rudiments of early life or recent acquisition?. Curr. Op. Chem. Biol. 2004, 8, 665-671.

260. Barnhart, M.M.; Chapman, M.R. Curli biogenesis and function. Annu. Rev. Microbiol. 2006, 60, 131-147.

261. Branda, S.S.; Vik, Å.; Friedman, L.; Kolter, R. Biofilms: the matrix revisited. Trends Microbiol. 2005, 13, 20-26.

262. Flemming, H.C.; Wingender J. The biofilm matrix. Nature Rev. Microbiol. 2010, 8, 623633.

263. Traverse, C.C.; Mayo-Smith, L.M.; Poltak, S.R.; Cooper, V.S. Tangled bank of experimentally evolved Burkholderia biofilms reflects selection during chronic infections. Proc. Natl. Acad. Sci. USA 2013, 110, E250-E259.

264. Hobley, L.; Harkins, C.; MacPhee, C.E.; Stanley-Wall, N.R. Giving structure to the biofilm matrix: an overview of individual strategies and emerging common themes. FEMS Microbial. Rev. 2015, 39, 649-669.

265. Berlanga, M.; Guerrero, R. Living together in biofilms: the microbial cell factory and its biotechnological implications. Microb. Cell Fact. 2016, 15, 165.

266. Decho, A.W.; Gutierrez, T. Microbial extracellular polymeric substances (EPSs) in ocean systems. Front. Microbiol. 2017, 8, 922.

267. Russell, M.J. The generation at hot springs of ores, microbialites and life. Ore Geol. Rev. 1996, 10, 199-214.

268. Wicken, J.S. Evolution, Thermodynamics and Information: Extending the Darwinian Program. Oxford University Press, 1987.

269. Peretó, J.; Bada, J.L.; Lazcano, A. Charles Darwin and the origin of life. Orig. Life Evol. Biosph. 2009, 39, 395-406.

270. Evenson, E. Charles Darwin - Geologist. Geol. Soc. Am. Abstracts with Programs, 2009, $41,243$.

271. Greene, M.T. Man, myth, geologist. Nature Geosci. 2009, 2, 666.

272. Polanyi, M. Personal Knowledge, Towards a Post-critical Epistemology. London, Routledge and Kegan Paul 1952. 
273. Pasteur, L. Mémoire sur les corpuscules organisés qui existent en suspension dans l'atmosphère. Examen de la doctrine des générations spontanées (Extrait). Compt. rend. 1861, 52, 1142-1143.

274. Fox Keller, E. Making sense of life: Explaining biological development with models, metaphors, and machines. Harvard University Press. Cambridge, MA: Harvard 2002

275. Ritson, D.J.; Battilocchio, C.; Ley, S.V.; Sutherland, J.D. Mimicking the surface and prebiotic chemistry of early Earth using flow chemistry. Nature Commun. 2018, 9, 1821.

276. Šešelja, D.; Straßer, C. Epistemic justification in the context of pursuit: A coherentist approach. Synthese 2014, 191, 3111-3141.

277. Russell, M.J. Discussion. Evolution of hydrothermal ecosystems on Earth (and Mars). In G.R. Bock, J.A. Goode, Eds. 1996, 202, 55.

278. Cairns-Smith, A.G. Genetic Takeover: and the Mineral Origins of Life. Cambridge University Press. 1982

279. Feynman, R. The character of physical law. MIT press, 2017.

280. Russell, M.J.; Hall, A.J.; Rahman, L.; Turner, D. Abiotic organic syntheses in deep submarine, alkaline hydrothermal systems catalysed by $\mathrm{Fe}^{0}$, mackinawite, violarite and green rust. In Eleventh Annual V.M. Goldschmidt Conference, 2001, Abstract \#3090. LPI Contribution No. 1088, Lunar and Planetary Institute, Houston

281. Lane, N. Why are cells powered by proton gradients. Nature Educ. 2010, 3, 2.

282. Astumian, R.D.; Mukherjee, S.; Warshel, A. The physics and physical chemistry of molecular machines. ChemPhysChem 2016, 17, 1719-1741.

283. Greenwell, H.C.; Jones, W.; Coveney, P.V.; Stackhouse, S. On the application of computer simulation techniques to anionic and cationic clays: A materials chemistry perspective. $J$. Mater. Chem. 2006, 16, 708-723.

284. Mitchell, P. The origin of life and the formation and organizing functions of natural membranes. In Proceedings of the First International Symposium on the Origin of Life on the Earth, A.I. Oparin, A.G. Pasynskiŭ, A.E. Brauntsteĭn, T.E. Pavlovskaya, Eds House Academy of Science, Moscow, USSR, 1957; English edition edited by F. Clark and R.L.M. 1959.

285. White, L.M. Exploring inorganic catalytic pathways for $\mathrm{CO}_{2}$ reduction: metal-oxide nanowires and iron sulfide minerals. PhD Thesis, University of California, Santa Barbara, 2013.

286. Baymann, F.; Schoepp-Cothenet, B.; Duval, S.; Guiral, M.; Brugna, M., Baffert, C.; Russell M.J.; Nitschke, W. On the natural history of flavin-based electron bifurcation. Front. Microbiol. 2018, 9, 1357.

287. Huang, S.P.; Shiota, Y.; Yoshizawa, K. DFT study of the mechanism for methane hydroxylation by soluble methane monooxygenase (sMMO): effects of oxidation state, spin state, and coordination number. Dalton Trans. 2013, 42, 1011-1023.

288. Roldan, A.; Hollingsworth, N.; Roffrey, A.; Islam, H.U.; Goodall, J.; Catlow, C. R.A.; Darr, J.A.; Bras, W.; Sankar, G.; Holt, K.B.; Hogarth G.; de Leeuw, N.H. Bio-Inspired $\mathrm{CO}_{2}$ conversion by iron sulfide catalysts under sustainable conditions. Chem. Comm. 2015, 51, 7501-7504.

289. Bar-Even, A. Formate assimilation: the metabolic architecture of natural and synthetic pathways. Biochem. 2016, 55, 3851-3863.

290. Kawamura, K.; Takeya, H.; Kushibe, T.; Koizumi, Y. Mineral-enhanced hydrothermal oligopeptide formation at the second time scale. Astrobiology 2011, 11, 461-469. 
291. Coveney, P.V.; Swadling, J.B.; Wattis, J.A.; Greenwell, H.C. Theory, modelling and simulation in origins of life studies. Chem. Soc. Rev. 2012, 41, 5430-5446.

292. Grégoire, B.; Erastova, V.; Geatches, D.L.; Clark, S.J., Greenwell, H.C.; Fraser, D.G. Insights into the behaviour of biomolecules on the early Earth: The concentration of aspartate by layered double hydroxide minerals. Geochim. Cosmochim. Acta 2016, 176, 239-258.

293. Zhang, P.; Yuly, J. L.; Lubner, C. E.; Mulder, D. W.; King, P. W.; Peters, J.W.; Zhang, P.; Yuly, J.L.; Lubner, C.E.; Mulder, D.W.; King, P.W.; Peters, J.W.; Beratan, D.N. Electron bifurcation: Thermodynamics and kinetics of two-electron brokering in biological redox chemistry. Acc. Chem. Res. 2017, 50, 2410-2417.

294. McGlynn, S.E. Energy metabolism during anaerobic methane oxidation in ANME archaea. Microbes and environments 2017, 32, 5-13.

295. Harford C.; Sarkar B: Amino terminal Cu(II) and Ni(II) binding ATCUN motif of proteins and peptides. Acc. Chem. Res. 1999, 30, 123-130.

296. De Duve, C. Blueprint for a cell: the nature and origin of life. 1991, Carolina Biological Supply Co.

297. Kitadai, N.; Nakamura, R.; Yamamoto, M.; Takai, K.; Li, Y.; Yamaguchi, A.; Gilbert, A.; Ueno, Y.; Yoshida, N.; Oono, Y. Geoelectrochemical CO production: Implications for the autotrophic origin of life. Science adv. 2018, 4, eaao7265.

298. Kitadai, N. Thermodynamic prediction of glycine polymerization as a function of temperature and $\mathrm{pH}$ consistent with experimentally obtained results. J. Mol. Evol. 2014, 78, 171-187.

299. Yin, W.; Huang, L.; Pedersen, E.B.; Frandsen, C.; Hansen, H.C.B. Glycine buffered synthesis of layered iron (II)-iron (III) hydroxides (green rusts). J. Colloid. Interface Sci. 2017, 497, 429-438.

300. Camprubi, E.; Jordan, S. F.; Vasiliadou, R.; Lane, N. Iron catalysis at the origin of life. IUBMB life 2017, 69, 373-381.

301. Cotton, C.A.; Edlich-Muth, C.; Bar-Even, A. Reinforcing carbon fixation: $\mathrm{CO}_{2}$ reduction replacing and supporting carboxylation. Curr. Op. Biotech. 2018, 49, 49-56.

302. Whicher, A.; Camprubi, E.; Pinna, S.; Herschy, B.; Lane, N. Acetyl phosphate as a primordial energy currency at the origin of life. Orig. Life Evol. Biosph. 2018, 48, 159-179. 